\title{
Recovery Plan for Laurel Wilt of Avocado, Caused by Raffaelea lauricola
}

\author{
Updated October 2016
}

R. C. Ploetz, Tropical Research and Education Center, University of Florida, Homestead 33031; M. A. Hughes, School of Forest Resources and Conservation, University of Florida, Gainesville 32611; P. E. Kendra, USDA-ARS Subtropical Horticulture Research Station, Miami, FL 33158; S. W. Fraedrich, USDA Forest Service, Athens, GA 30602; D. Carrillo, Tropical Research and Education Center, University of Florida, Homestead 33031; L. L. Stelinski, Citrus Research and Education Center, University of Florida, Lake Alfred 33850; J. Hulcr, School of Forest Resources and Conservation and Department of Entomology and Nematology, University of Florida, Gainesville 32611; A. E. Mayfield, III, USDA Forest Service, Southern Research Station, Asheville, NC 28804; T. J. Dreaden, USDA-Forest Service, Southern Research Station, Forest Health Research and Education Center, Lexington, KY 40517; J. H. Crane, E. A. Evans, and B. A. Schaffer, Tropical Research and Education Center, University of Florida, Homestead 33031; and J. A. Rollins, Department of Plant Pathology, University of Florida, Gainesville 32611

Accepted for publication 11 February 2017.

Ploetz, R. C., Hughes, M. A., Kendra, P. E., Fraedrich, S. W., Carrillo, D., Stelinski, L. L., Hulcr, J., Mayfield, A. E., III, Dreaden, T. J., Crane, J. H., Evans, E. A., Schaffer, B. A., and Rollins, J. A. 2017. Recovery plan for laurel wilt of avocado, caused by Raffaelea lauricola. Plant Health Prog. 18:51-77. doi:10.1094/PHP-12-16-0070-RP

Table of Contents

Executive Summary ...............................................................................52

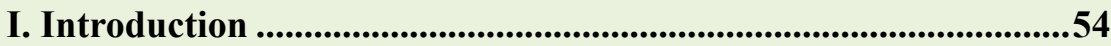

II. Disease Cycle and Symptom Development ......................................55

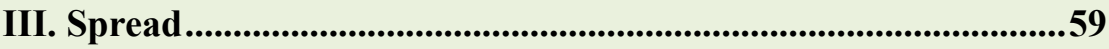

IV. Monitoring and Detection................................................................66

V. Response ..................................................................................................65

VI. Permits and Regulatory Issues ...............................................66

VII. Economic Impacts ..................................................................66

VIII. Mitigation and Disease Management.........................................667

IX. Infrastructure and Experts ....................................................69

X. Research, Extension, and Education Priorities ............................. 71

XI. Timeline for Recovery .......................................................................71

X. References ...........................................................................................72

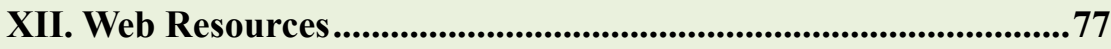

Corresponding author: Randy Ploetz. E-mail: kelly12@ufl.edu

* The $e$-Xtra logo stands for "electronic extra"; see the journal site for seven supplemental figures.

http://dx.doi.org/10.1094/PHP-12-16-0070-RP
This article is in the public domain and not copyrightable. It may be freely reprinted with customary crediting of the source.

The American Phytopathological Society, 2017 
This recovery plan is one of several disease-specific documents produced as part of the National Plant Disease Recovery System (NPDRS) called for in Homeland Security Presidential Directive Number 9 (HSPD-9). The purpose of the NPDRS is to insure that the tools, infrastructure, communication networks, and capacity required to mitigate the impact of high-consequence plant disease outbreaks are such that a reasonable level of crop production is maintained.

Each disease-specific plan is intended to provide a brief primer on the disease, assess the status of critical recovery components, and identify disease management research, extension, and education needs. These documents are not intended to be stand-alone documents that address all of the many and varied aspects of plant disease outbreak, all of the decisions that must be made, and actions taken to achieve effective response and recovery. They are, however, documents that will help USDA-APHIS guide further efforts directed toward plant disease recovery.

\section{Executive Summary}

Laurel wilt kills American members of the Lauraceae plant family, including avocado (Persea americana), an important commercial fruit crop. The disease threatens commercial production in the United States and other countries, and currently impacts the avocado industry in Florida. As laurel wilt spreads, the National Germplasm Repository for avocado in Miami (USDA-ARS) and commercial and residential production in other states (e.g., California and Hawaii), U.S. protectorates (Puerto Rico), and other countries are at risk. In the United States, value-added production of avocado of more than $\$ 1.3$ billion/year is threatened.

Laurel wilt is caused by Raffaelea lauricola, a nutritional symbiont of an Asian ambrosia beetle, Xyleborus glabratus. Laurel wilt was first recognized around Savannah, GA, in 2003, and has since devastated native populations of redbay (P. borbonia) and other native species in the family in the southeastern United States. The first avocado tree was killed by laurel wilt in Jacksonville, FL (2006), and soon after, a southward swath of host trees began to die down the eastern flank of the state. In February 2011, the disease was confirmed adjacent to the Everglades on swamp bay ( $P$. palustris), and by November of that year had spread to Florida's primary commercial avocado production area (CAPA) in southeastern Miami-Dade Co. Within 2 years, the disease had spread throughout the CAPA. Where insufficient or delayed implementtation of control measures were used, the disease spread rapidly, resulting in lost commercial viability and orchard abandonment. Avocado production continues in areas of Florida to which laurel wilt has not spread and where the disease has been effectively managed. Excluding laurel wilt from healthy avocado orchards and managing the disease in affected orchards is a major, ongoing challenge.

Laurel wilt has spread along the eastern seaboard of the United States due to the mobile insect vector, X. glabratus; the movement of wood infested with the insect and pathogen; and the presence of native and non-native plants that are susceptible to the disease and in which X. glabratus reproduces. Rapid spread has occurred where there are (were) high population densities of redbay and swamp bay. In avocado, the species of ambrosia beetles that disseminate $R$. lauricola are not well defined. In addition, the pathogen likely moves via avocado root grafts, but dissemination via pruning equipment, fruit, seed, or scion material is unlikely.

Diverse disease management strategies have been examined for avocado, including host resistance and the use of fungicides and insecticides. To date, no highly efficacious and cost-effective measure has been identified. In the absence of such a measure, holistic considerations of host tolerance and chemical mitigation will be needed. Cultural measures, notably the prompt identification and removal of infected trees (sanitation), are needed to ensure that pathogen movement to adjacent trees via 
root grafts, as well as the reproduction of ambrosia beetle vectors, does not occur or is minimized.

Unexpected insights have emerged with nearly every new research finding on this disease. Laurel wilt is unique in that symbionts of ambrosia beetles are rarely plant pathogens and were not known previously to be systemic (one inoculation with $R$. lauricola is sufficient to colonize and kill an entire tree). Lateral transfer of the pathogen to at least nine other species of ambrosia beetle has occurred since X. glabratus was introduced to the United States, some of which have transmitted the pathogen to redbay and avocado experimentally. Surprisingly, X. glabratus is rarely trapped in laurel wilt-affected commercial orchards or reared from laurel wilt-affected bolts from the CAPA. Root-graft transmission of the pathogen, difficult detection and inconsistent distributions of the fungus in affected trees, poor resistance to the disease in avocado, and the expense of chemical and cultural measures have complicated management efforts. Improved control measures will rely on better understandings of the host $\times$ pathogen interaction, as well as the epidemiology of laurel wilt in avocado orchards and surrounding areas. The identities and dynamics of different vectors in the disease cycle, and ways in which pesticide efficacy, longevity, and distribution could be increased in treated trees, also need to be better understood.

American members of the Lauraceae are usually more susceptible to the disease than are those from the beetle's Asian home range. Limited information is available on the extent to which lauraceous and non-lauraceous taxa serve as hosts and reservoirs for $R$. lauricola, X. glabratus, and other potential ambrosia beetle vectors. Features of laurel wilt-tolerant, Asian taxa in the Lauraceae (e.g., camphortree, Cinnamomum camphora) may provide clues about attributes that would enhance resistance in different avocado genotypes.

Good progress has been made in understanding this disease. Nonetheless, continued work on the most pressing issues is still required, as it is unclear what actions would be used cost-effectively in commercial avocado-production areas.

(i) Research on the efficacy and cost-effectiveness of chemical controls measures (fungicides, and insecticides, attractants and repellents of ambrosia beetle vectors) must continue as these may ultimately provide important components of a multifaceted management scheme.

(ii) Ongoing work to identify disease tolerance in avocado should continue. Thus far, it appears that insufficient tolerance exists among the cultivars that are currently grown in Florida, and that new cultivars and genotypes may be needed if resistance is to play a significant role in addressing this disease. Currently, manipulation of the response of susceptible West Indian cultivars is being investigated with different clonal rootstocks, as the selection and development of resistant and commercially acceptable cultivars would be a long process.

(iii) Data are needed on the impact of ambrosia beetles other than $X$. glabratus in the movement of $R$. lauricola to healthy avocado and other lauraceous taxa, and the extent to which they spread the disease. (iv) State, federal, and international regulations on the movement of firewood and untreated yard and forest waste are needed, as the longdistance transport of the same has resulted in significant jumps in the distribution of this disease during its brief history in the southeastern United States and will likely result in the continued spread of this disease. Regulations recently enacted or proposed in Florida (see VI. Permit and Regulatory Issues) provide useful models for what could be considered in other states.

(v) State and federal efforts to educate stakeholders on the disease and its mitigation should continue.

(vi) Duplication of important Avocado sunblotch viroid (ASBVd)-free accessions in the USDA-ARS repository for avocado germplasm and 
their transfer and establishment at the USDA-ARS facility in Hilo, HI, should continue.

\section{Introduction}

Laurel wilt affects members of the Lauraceae plant family (Laurales, Magnoliid complex), and is caused by a fungal symbiont, Raffaelea lauricola (Ophiostomatales), of an Asian ambrosia beetle, Xyleborus glabratus (Curculionidae: Scolytinae) (Fraedrich et al. 2008). Starting in its probable epicenter of Port Wentworth, GA, the disease had been confirmed by August 2016 in nine states as far west as Hardin Co., TX $\left(30^{\circ} \mathrm{N}\right.$ and $\left.95^{\circ} \mathrm{W}\right)$, as far east as Onslow Co., $\mathrm{NC}\left(34^{\circ} \mathrm{N}\right.$ and $\left.78.5^{\circ} \mathrm{W}\right)$, as far north as Sampson Co., $\mathrm{NC}\left(35^{\circ} \mathrm{N}\right.$ and $\left.79^{\circ} \mathrm{W}\right)$, and as far south as Miami-Dade Co., FL $\left(25.5^{\circ} \mathrm{N}\right.$ and $80.5^{\circ} \mathrm{W}$ ) (Barton et al. 2016) (Fig. 1). Although virtually all of these outbreaks have occurred on native host trees (Hughes et al. 2015b), commercial production of a tropical American crop in the family, avocado (Persea americana), was affected in Florida beginning in 2012 (Ploetz et al. 2013).

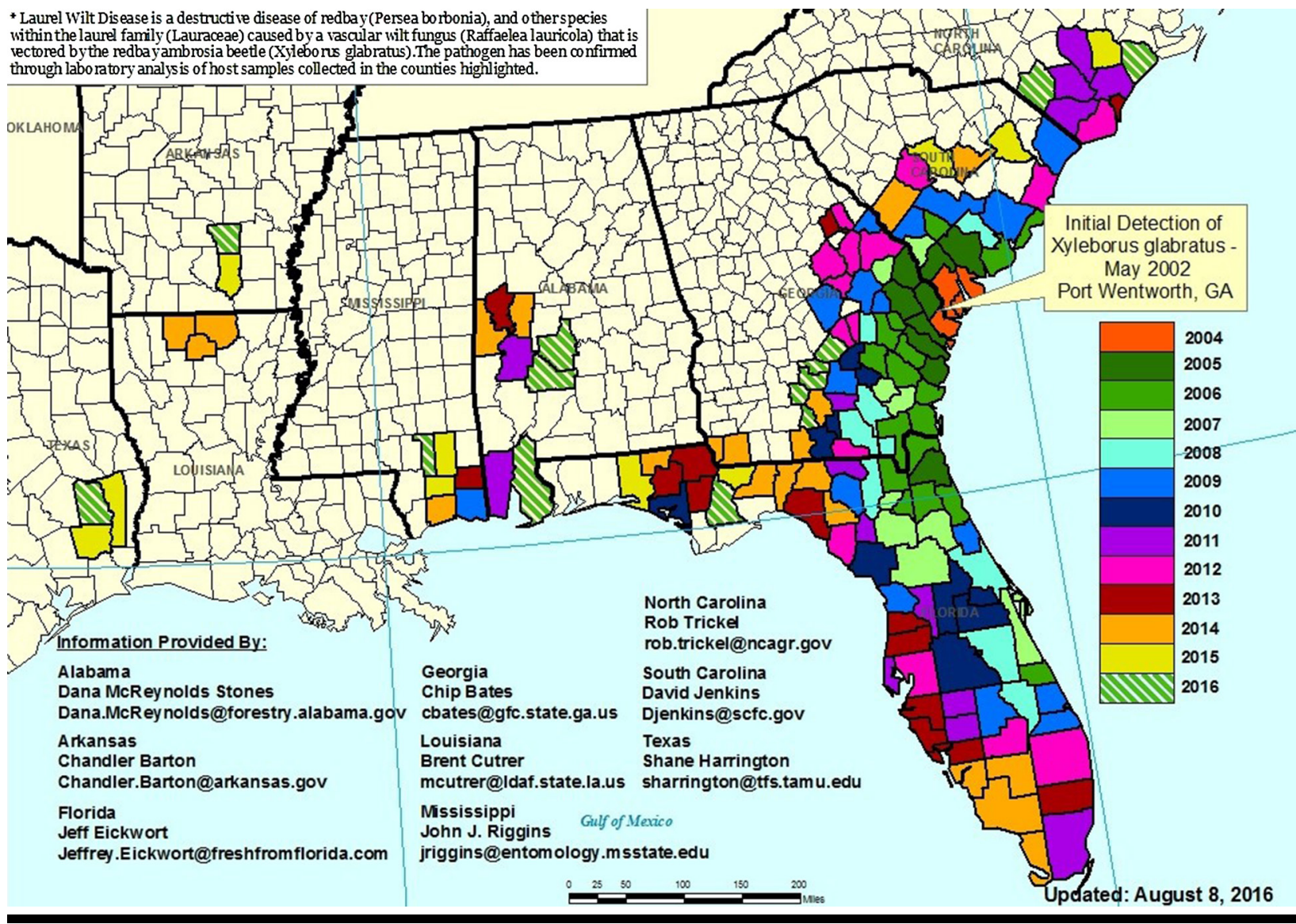

FIGURE 1

Laurel wilt distribution in southeastern United States.

Harrington et al. (2011) recovered $R$. lauricola from specimens of X. glabratus from Japan and Taiwan, corroborating the assumption that the pathogen arrived in the United States with $X$. glabratus. Since there are no reports of laurel wilt prior to 2003, it is probable: (i) that the beetle carried the pathogen when it was first detected in Port Wentworth in 2002 (Haack 2006; Rabaglia et al. 2006); (ii) that introduction established the beetle and pathogen in the United States (Harrington et al. 2011); and (iii) American suscepts in the Lauraceae are all new-encounter, so-called naïve hosts (Ploetz et al. 2013). A single, asexually reproducing clone of $R$. lauricola is respon- 
sible for the laurel wilt epidemic in the United States (Hughes 2013), which suggests that the current epidemic in the United States is due to single founding event (invasion).

Although some species, such as Xylosandrus compactus, cause primary damage (Ngoan et al. 1976; Ranger et al. 2010), ambrosia beetles usually colonize and reproduce in stressed or dead trees. This has led to a general assumption that most ambrosia beetle species do not interact with healthy, non-stressed trees, and that the interaction between $X$. glabratus and trees that are susceptible to laurel wilt is unusual, since healthy trees are attacked to initiate the disease cycle (Hulcr and Dunn 2011; Kühnholz et al. 2001). However, how X. glabratus colonizes trees is poorly understood. Fraedrich et al. (2008) indicated that X. glabratus may not colonize healthy host trees, but that its initial interaction with these trees is sufficient to infect them with $R$. lauricola. A primary reason this beetle is known to interact with healthy trees is that it carries a lethal, systemic pathogen. If other beetle species interacted with healthy trees their activities might not be recognized unless they caused conspicuous damage or carried a lethal pathogen (Ploetz et al. 2013).

Critical gaps exist in what is known about the development and epidemiology of laurel wilt on avocado. The interaction of susceptible host tree species and $R$. lauricola is incompletely understood, as is the nature of tolerance to the disease (Ploetz et al. 2015). Information is needed on pathogen and host attributes that result in compatible and incompatible disease responses, as it could enable the selection of resistant genotypes and may assist the development of better disease diagnostics. Considering the large number of species in, and the wide geographic distribution of, the Lauraceae, more data are needed on the reactions of different species in the family to the pathogen as they could help improve management strategies, predict and explain the disease's spread, and plan research on the host $\times$ pathogen interaction. Much remains to be learned about the identity and biology of vector(s) of this pathogen. Xyleborus glabratus is rare in the CAPA. Since $R$. lauricola is carried by other ambrosia beetle species in the CAPA (Ploetz et al. 2017a), several of which have experimentally transmitted the pathogen to avocado and swamp bay (Persea palustris), the role of species other than X. glabratus should be considered (Carrillo et al. 2014; Ploetz et al. 2013). Little is known about the interaction of $R$. lauricola and other beetles that carry the pathogen, and virtually nothing is known about the management and attraction of the other species to avocado.

\section{Disease Cycle and Symptom Development}

Although details are known about the $X$. glabratus interaction with several host trees in the United States (Hughes et al. 2015b; Kendra et al. 2014a), very little is known about the identity and life cycles of the vectors in the avocado system (see III. Spread). This section deals primarily with the host $\times$ pathogen interaction.

Inoculation with as few as 100 conidia of $R$. lauricola can kill avocado and swamp bay (Hughes et al. 2015a). Xylem function (the ability to conduct water) is impaired as soon as 3 days after inoculation, before the development of external or internal symptoms of the disease are apparent (Fig. 2) (Inch et al. 2012). Reductions in xylem function that develop in these plants are correlated with increased tylose formation in xylem lumena and the eventual development of symptoms (Figs. 2 and 3) (Inch et al. 2012; Inch and Ploetz 2012). Tree mortality is associated with functionalities of less than $10 \%$.

Tylose induction in susceptible cultivars is poorly understood. Although a maximum of $0.4 \%$ of the lumena were colonized by a green fluorescent protein (gfp)labelled strain of the pathogen in microscopic cross sections, 30 days after inoculation (Fig. 4A) (Campbell et al. 2017), in another study about $40 \%$ of the lumena were occluded by tyloses 21 days after inoculation (Fig. 3E) (Inch et al. 2012). Mobility of 
A

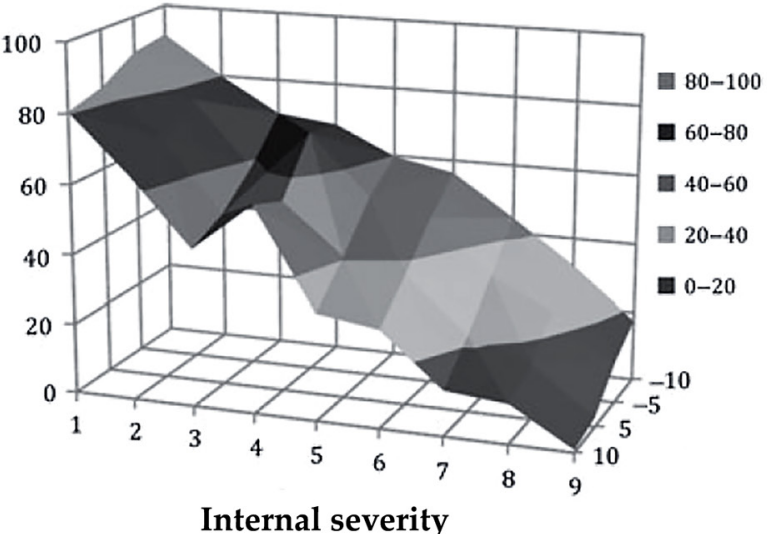

B

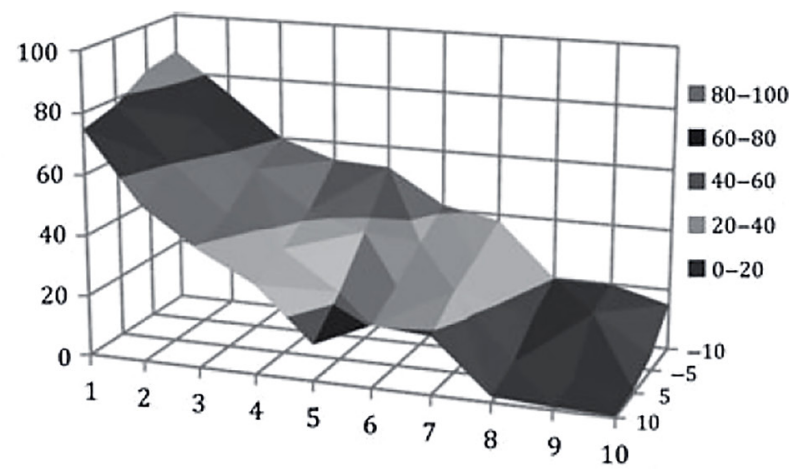

C
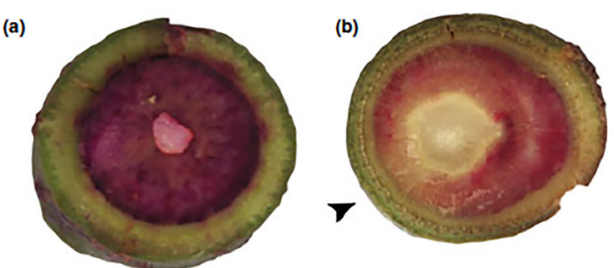

(c)

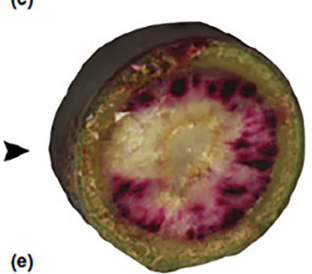

(d)

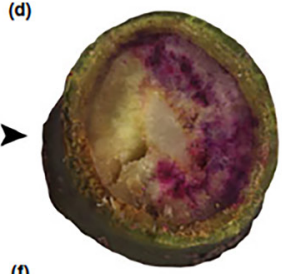

(f)
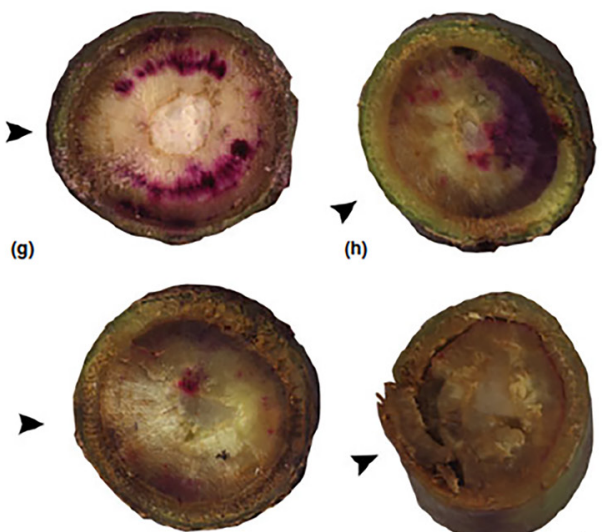

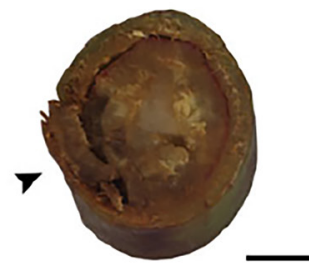

\section{FIGURE 2}

'Simmonds' avocado trees were inoculated with Raffaelea lauricola and examined for (A) the development of internal (sapwood discoloration) and (B) external (foliar wilting and necrosis) symptoms of laurel wilt on a 1-to-10 scale ( $\mathrm{x}$ axes), wherein $1=$ healthy, no symptoms, and $10=$ dead, totally symptomatic, and percent (\%) xylem function (y-axes), as determined with an acid fuchsin assay. The $z$-axes indicate the distances above (+) and below (-) the inoculation points on stems. In the stem cross sections in (C), burgundy to pink coloration (acid fuchsin staining) indicates functional xylem, which was quantified in scanned, digital images: (a) $98 \%$ functional (water control, internal symptoms (IS) $=1$; (b) $86 \%$ (3 days after inoculation (dai), IS = 1; (c) 76\% (7 dai, IS = 2); (d) $71 \%$ ( 14 dai, IS = 3); (e) $32 \%$ ( 21 dai, IS = 5); (f) $30 \%$ (21 dai, IS = 6; (g) $5 \%$ (42 dai, IS = 9; and (h) $1 \%$ (42 dai, IS = 9). Scale bar $=0.5 \mathrm{~cm}$.
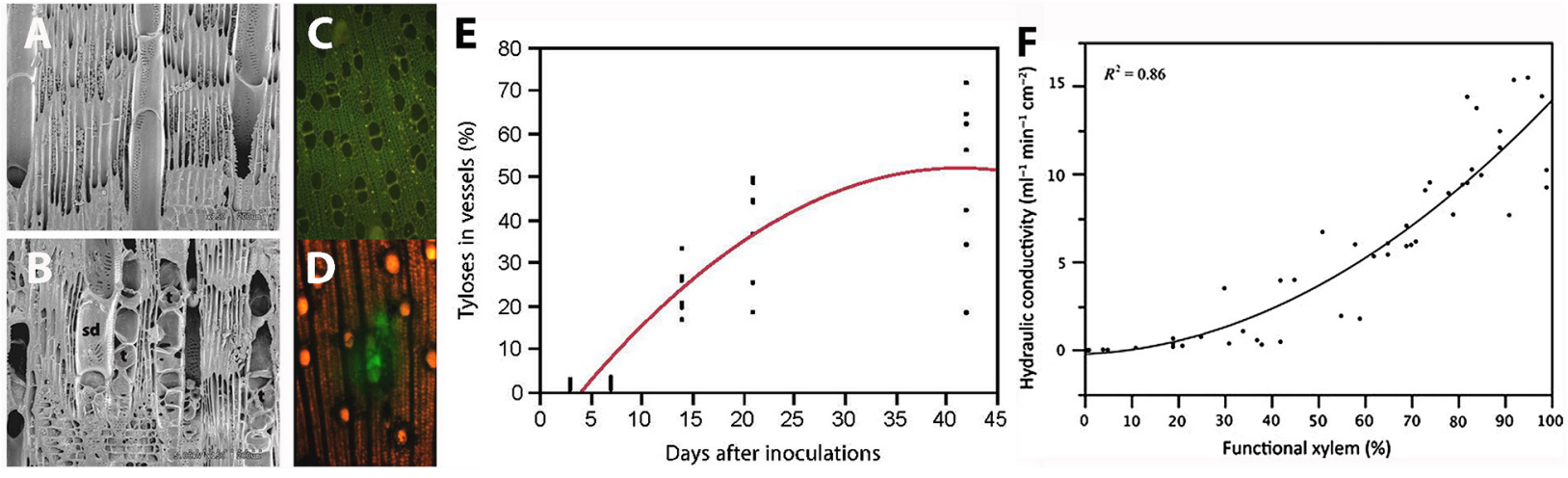

FIGURE 3

Raffaelea lauricola induces tylose formation in infected avocado trees, but is scarcely evident, microscopically. In scanning electron micrographs, tyloses are (A) absent in vessel lumena in noninoculated trees, but are (B) prevalent 21 days after inoculation. Ten days after inoculation, a GFP-marked strain of the pathogen is: (C) not visible until (D) 5 days after a bioenrichment step. The percentage of vessel cross-sections that are occluded with tyloses $(\mathbf{E})$ increases soon after inoculation $\left(R^{2}=0.78 ; P<0.0001 ; y=-0.69+1.79 x-0.04(x-17.4)^{2}\right)$, and xylem dysfunction that is associated with tylose presence $(\mathbf{F})$ is related to reduced hydraulic conductivity $\left(R^{2}=0.86 ; P<0.001 ; y=-4.25+0.16 x+0.001 x^{2}\right)$. 
the pathogen (or its metabolites) in the xylem seems to be related to susceptibility, since sap flow rates were significantly higher in a susceptible versus less susceptible cultivars, before inoculation (Ploetz et al. 2015); however, sap flow plummeted in the susceptible cultivar soon after inoculation. In the analogous Dutch elm disease pathosystem, relatively high sap flow rates were predictors of susceptibility (Solla et al. 2005; Venturas et al. 2014).

Colonization of host trees in the Lauraceae by $R$. lauricola was investigated by Campbell et al. (2017). Moderate to severe disease developed on trees of avocado and swamp bay, whereas little to no disease developed on camphortree (Cinnamomum camphora) (Fig. 4B). Susceptibility and the extent to which these hosts were colonized were related, in that a greater microscopic presence of $R$. lauricola in xylem lumena and greater colonization of sapwood were observed in swamp bay and avocado compared to that in camphortree (Figs. 4A and 5).

Some of the symptoms of laurel wilt on avocado resemble those caused by other diseases or abiotic factors. Lightning, over-production of fruit and frost damage can kill all or portions of tree canopies, as can different diseases, in particular Phytophthora root rot, caused by P. cinnamomi, and Verticillium wilt, caused by $V$. dahliae. Vascular discoloration similar to that caused by laurel wilt also develops in trees affected by Verticillium wilt.

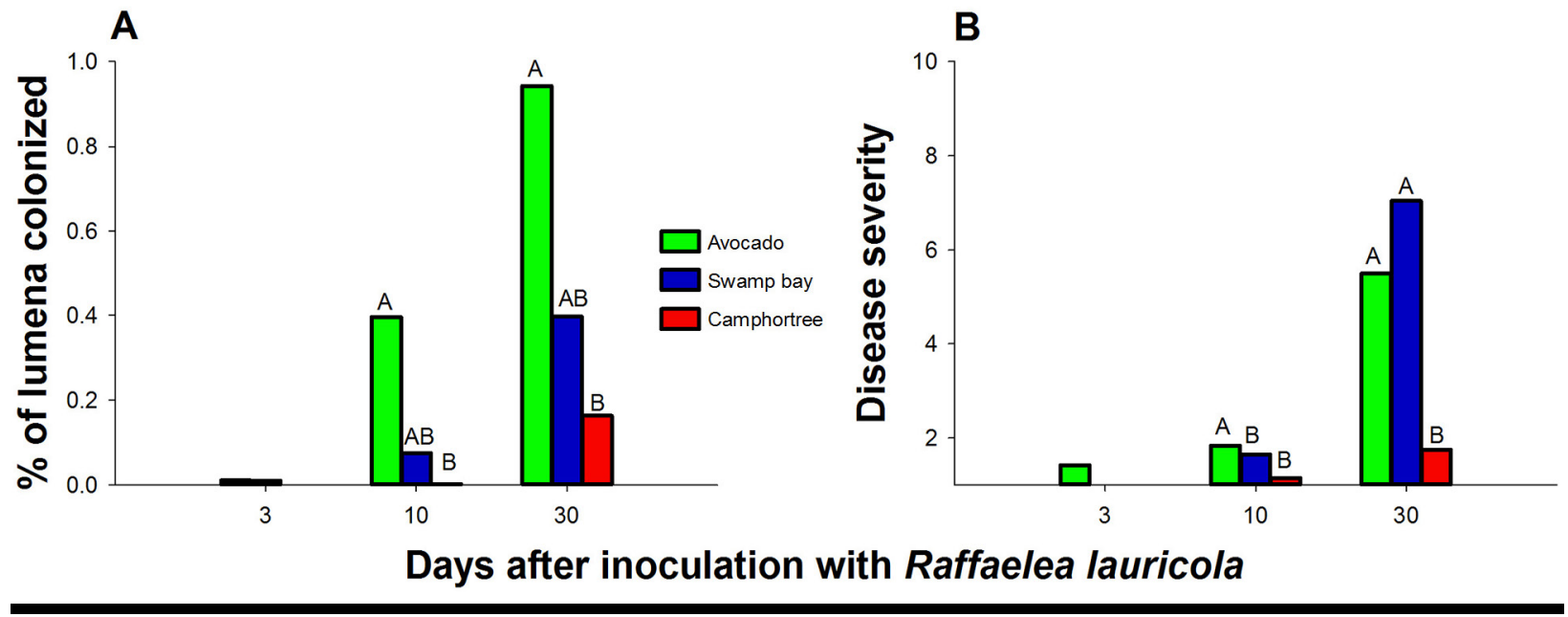

\section{FIGURE 4}

Avocado, swamp bay, and camphortree respond differently to artificial inoculation with Raffaelea lauricola. After 30 days, (A) colonization of lumena cross-sections by a gfp-marked strain of the pathogen varied by host, and (B) more disease developed on swamp bay and avocado, than on camphortree.
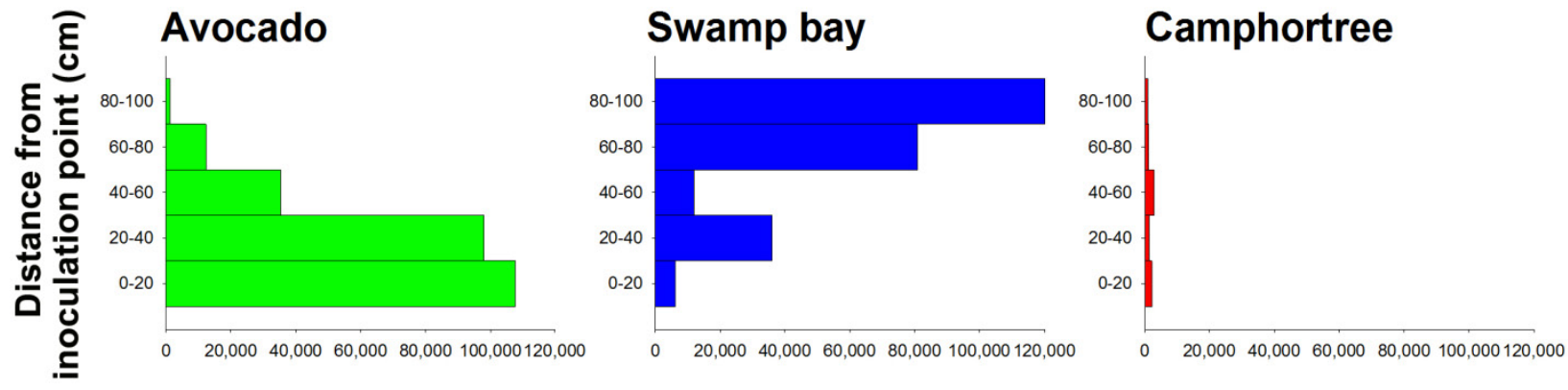

\section{Colony forming units of Raffaelea lauricola}

\section{FIGURE 5}

Thirty days after inoculation, colonization of swamp bay, avocado, and camphortree by Raffaelea lauricola, quantitated as colony-forming units of the pathogen per gram of sapwood, varied by species and distance from the inoculation point. 
The first external foliar symptoms of laurel wilt on avocado are wilting of terminal leaves that change from an oily green to brown color soon after wilting (Fig. 6A). Symptoms typically develop rapidly in affected portions of the tree (Fig. 6B), but production of healthy branches beneath affected regions in the tree (Fig. 6C) or the unilateral development of symptoms in which only a branch or a portion of a tree are affected also occurs (Fig. 6B). Unlike laurel wilt-affected redbay (Persea borbonia), which retains dead leaves for a year or longer, avocado defoliates within 2 to 9 months of symptom initiation (Fig. 6C). Internally, affected avocado sapwood is discolored reddish brown to bluish grey (Fig. 6D).

In artificial inoculation studies, moderate internal symptoms develop on avocado before external symptoms are evident (Ploetz et al. 2012b). On a 1 to 10 scale, where $1=$ no symptoms and $10=$ dead or completely symptomatic, internal severities can reach 5 before external severities are evident (Fig. 2). The threshold between internal and external symptoms has important implications for disease management since it is doubtful that systemic fungicides would be very effective if they were applied after external symptoms of the disease began to develop, owing to decreased mobility and distribution of fungicides in the nonfunctional xylem in such trees (Figs. 2 and 3).

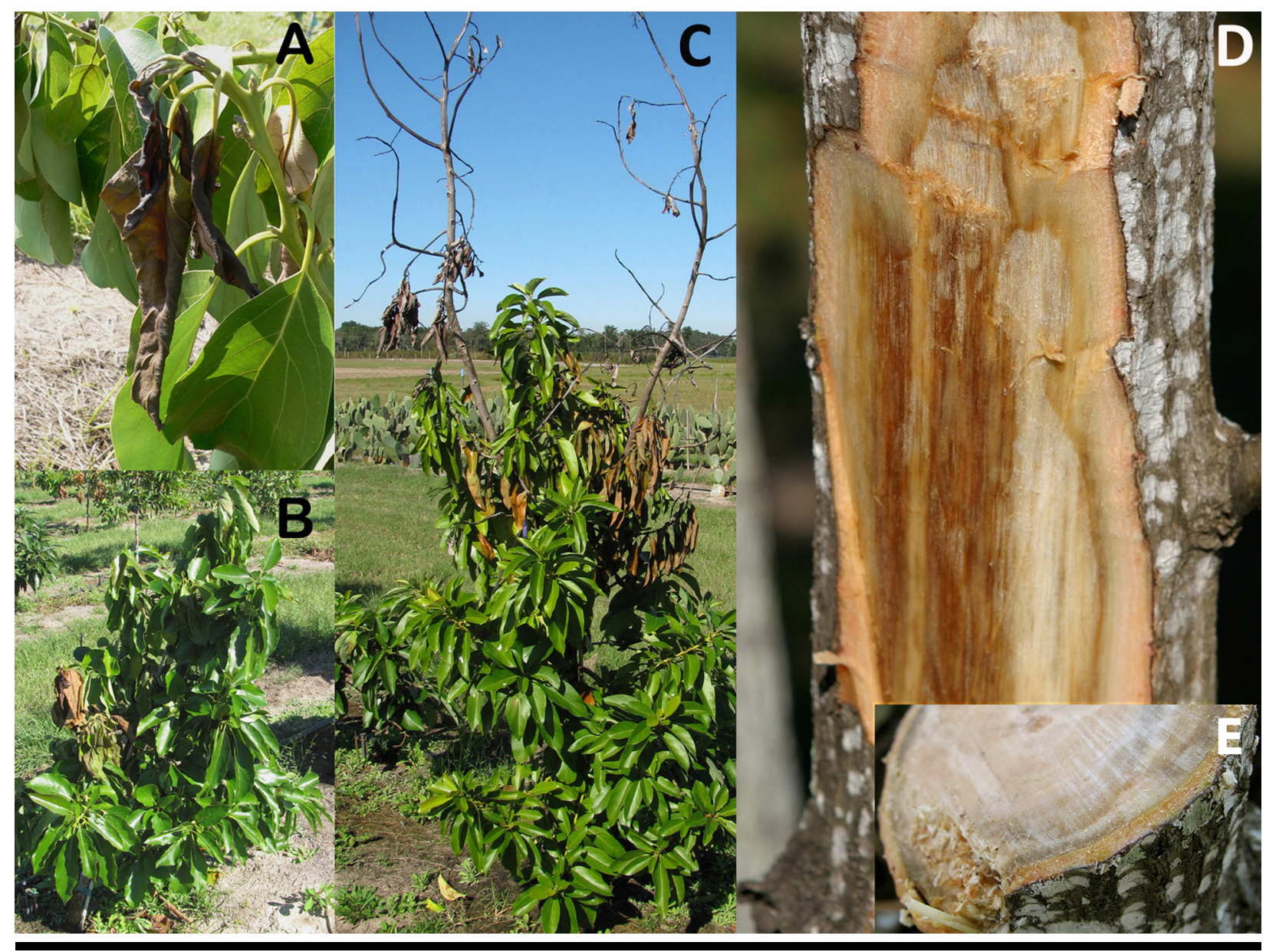

FIGURE 6

Symptoms of laurel wilt on avocado include: (A) oily green foliage that necroses to a brown color, (B) sectoral development of symptoms in which only a portion of the tree is affected, $(\mathbf{C})$ defoliation in portions of the tree that developed symptoms first, and (D) and (E) discoloration of sapwood. (A) to (C) are 'Simmonds' trees that were artificially inoculated with Raffaelea lauricola, and (D) and (E) are from branches of fruit-bearing trees in the field (photos: R. C. Ploetz). 


\section{Spread}

Lateral movement of fungal symbionts from one species to another is known in both bark beetles (Six 2003) and ambrosia beetles (Batra 1966; Carrillo et al. 2014; Gebhardt et al. 2004; Kostovcik et al. 2015; Ploetz et al. 2017a). To date, 17 ambrosia beetle species have been detected on avocado (Carrillo et al. 2012, 2014, unpublished; Kendra et al. 2011b) (Suppl. Fig. 1). In the United States, R. lauricola has been isolated from nine species of ambrosia beetles other than X. glabratus (Carrillo et al. 2014; Harrington and Fraedrich 2010; Ploetz et al. 2012, 2017a). All of the other species occurred in the United States prior to the introduction of X. glabratus and, presumably, obtained the fungus in laurel wilt-affected trees after that introduction (Ploetz et al. 2013).

More propagules of $R$. lauricola have been detected in X. glabratus than in any of the other species (Carrillo et al. 2014; Harrington et al. 2010; Ploetz et al. 2017a). However, X. glabratus appears to be far more prevalent and important on native trees from the southeastern United States than on avocado (Carrillo et al. 2012; Hanula et al. 2008; Mayfield and Hanula 2012). In recent surveys in Miami-Dade Co., FL, it was the most prevalent species recovered from laurel wilt-affected swamp bay $(47.8 \%$ of all identified individuals), but was not trapped in laurel wilt-affected avocado orchards or reared from laurel wilt-affected avocado wood ( 0 of 79,025 ambrosia beetles that were recovered) (Table 1). And in an earlier survey in Brevard Co., $X$. glabratus was reared from two of four laurel wilt-affected avocado trees, but at very low numbers ( 11 of a total of 4,181 individual beetles that were collected) (Carrillo et al. 2012). Thus, despite its prevalence in swamp bay, X. glabratus has hardly ever been associated with avocado.

The rarity of $X$. glabratus in avocado orchards in South Florida and the presence of $R$. lauricola in other beetle species suggests that other species could be vectors in the avocado pathosystem. Raffaelea lauricola has been recovered consistently from Xyleborus ferrugineus, Xyleborus bispinatus, and Xyleborus volvulus that were reared from swamp bay and avocado, but was found infrequently in two of the most common species in swamp bay and avocado, Xylosandrus crassiusculus and Xyleborinus saxeseni, and was present in Xyleborus affinis and Xyleborinus gracilis from swamp bay

\begin{tabular}{|c|c|c|c|c|c|c|}
\hline \multirow[b]{4}{*}{ Species } & sia beet & $\begin{array}{r}\text { TAE } \\
\text { om laure } \\
\text { I Miami-I }\end{array}$ & $\begin{array}{l}1 \\
\text { It-affect } \\
\text { e Co., Ft }\end{array}$ & ocado o & ards an & \\
\hline & \multicolumn{4}{|c|}{ Avocado } & \multirow{2}{*}{\multicolumn{2}{|c|}{$\begin{array}{c}\text { Swamp bay } \\
\text { Reared from bolts } \\
\end{array}$}} \\
\hline & \multicolumn{2}{|c|}{ Trapped in orchardsw } & \multicolumn{2}{|c|}{ Reared from bolts $x$} & & \\
\hline & ny & $\%$ total & ny & $\%$ total & ny & $\%$ total \\
\hline Xyleborus glabratus & 0 & 0 & 0 & 0 & 25,823 & 47.8 \\
\hline Xyleborus affinis & 13,814 & 22.0 & 2,053 & 12.7 & 4,411 & 8.2 \\
\hline Xyleborus bispinatus & 1,348 & 2.1 & 69 & 0.4 & $z$ & $z$ \\
\hline Xyleborus ferrugineus & 441 & 0.7 & 53 & 0.3 & 3,456 & 6.4 \\
\hline Xyleborus volvulus & 7,274 & 11.6 & 1,856 & 11.5 & 9,685 & 17.9 \\
\hline Xylosandrus crassiusculus & 11,761 & 18.7 & 8,533 & 52.7 & 1,479 & 2.7 \\
\hline Xyleborinus gracilis & 117 & 0.2 & 47 & 0.3 & 8,097 & 15.0 \\
\hline Xyleborinus saxeseni & 28,067 & 44.7 & 3,592 & 22.2 & 422 & 0.8 \\
\hline Totals & 62,822 & & 16,203 & & 53,979 & \\
\hline Grand totals & 79,025 & & & & 53,979 & \\
\hline
\end{tabular}

w Beetles were trapped in 13 avocado groves that were affected by laurel wilt.

x Bolts from 75 laurel wilt-affected avocado trees and 17 swamp bay trees were incubated for recovery of ambrosia beetles as described by Carrillo et al. $(2012,2014)$.

$\mathrm{y}_{\mathrm{n}}=$ total numbers of a given species that were recovered.

${ }^{\mathrm{z} X y l e b o r u s ~ b i s p i n a t u s ~ w a s ~ d i s t i n g u i s h e d ~ f r o m ~ X y l e b o r u s ~ f e r r u g i n e u s ~ i n ~ l a t t e r ~ w o r k ~ o n ~ a v o c a d o, ~ b u t ~ n o t ~ d u r i n g ~}$ work on swamp bay (Atkinson et al. 2013; Carrillo et al. 2012). 
but not from avocado (Tables 2 and 3). Among the most common species that were associated with avocado (Table 1), only reared Xyleborus volvulus harbored appreciable amounts of the pathogen (Table 3). Overall, $R$. lauricola was recovered less often from beetles trapped in laurel-affected avocado orchards (mean recovery of $1.6 \%)$ than from beetles reared from laurel wilt-affected avocado bolts (11.1\%) (Table $3)$.

TABLE $\mathbf{2}$
Recovery of Raffaelea lauricola from ambrosia beetles reared from
laurel wilt-affected swamp bay trees

x Recovery of $R$. lauricola from individuals of the different species was described by Carrillo et al. (2014). $\mathrm{n}=$ number of individuals that were assayed, $\mathrm{CFU}=$ colony forming unit of $R$. lauricola on a semi-selective medium, and SEM = standard error of the mean. Means followed by the same letter within columns are not significantly different at $P<0.05$. The PROC GLIMMIX procedure (SAS v. 9.32012 ) was used to assess differences in the percentage values, and the Steel-Dwass method (SAS v. 9.3 2012) was used for non-parametric paired comparisons of mean CFUs of R. lauricola in the different beetle species.

y In olfactometer assays, Xyleborus glabratus was attracted to Raffaelea lauricola, Xyleborus ferrugineus did not respond, and Xylosandrus crassiusculus and Xyleborinus saxeseni were repelled (Hulcr et al. 2011).

${ }^{\mathrm{z} X y l e b o r u s ~ b i s p i n a t u s ~ w a s ~ d i s t i n g u i s h e d ~ f r o m ~ X y l e b o r u s ~ f e r r u g i n e u s ~ i n ~ l a t t e r ~ w o r k ~ o n ~}$ avocado, but not during work on swamp bay (Atkinson et al. 2013).

\begin{tabular}{|c|c|c|c|c|c|c|c|c|c|c|}
\hline \multirow[b]{3}{*}{ Species } & \multicolumn{9}{|c|}{$\begin{array}{l}\text { TABLE } 3 \\
\text { RI) from ambrosia beetles associated with } \\
\text { ffected avocado trees }\end{array}$} & \\
\hline & \multicolumn{5}{|c|}{ Trapped in laurel wilt-affected orchards } & \multicolumn{5}{|c|}{ Reared from laurel wilt-affected bolts } \\
\hline & $\mathbf{n}^{\mathbf{x}}$ & $\begin{array}{l}\text { No. } \\
\text { w/RI }\end{array}$ & $\begin{array}{c}\% \\
\text { beetles } \\
\text { w/RI }\end{array}$ & $\underset{ \pm \text { mean }}{\text { MFU }}$ & $\begin{array}{l}\text { CFU } \\
\text { rangex }\end{array}$ & $\mathbf{n}^{\mathbf{x}}$ & $\begin{array}{l}\text { No. } \\
\text { w/ Ri }\end{array}$ & $\begin{array}{c}\% \\
\text { beetles } \\
\text { w/Rl }\end{array}$ & $\underset{\substack{\text { mean } \\
\pm S E M}}{C F U}$ & $\underset{\text { range }^{\mathrm{C}}}{\mathrm{CFU}}$ \\
\hline Xyleborus glabratus ${ }^{\mathrm{y}}$ & $0^{\mathrm{z}}$ & $\mathrm{n} / \mathrm{a}$ & $\mathrm{n} / \mathrm{a}$ & $\mathrm{n} / \mathrm{a}$ & $\mathrm{n} / \mathrm{a}$ & $0^{\mathrm{z}}$ & $\mathrm{n} / \mathrm{a}$ & $\mathrm{n} / \mathrm{a}$ & $\mathrm{n} / \mathrm{a}$ & $\mathrm{n} / \mathrm{a}$ \\
\hline Xyleborus affinis & 50 & 0 & 0 & 0 & 0 & 16 & 0 & 0 & 0 & 0 \\
\hline Xyleborus bispinatus & 14 & 1 & 7 & $0.1 \pm 0.1$ & $0-2$ & 5 & 5 & 100 & $41 \pm 16$ & $4-80$ \\
\hline Xyleborus ferrugineus ${ }^{\mathrm{y}}$ & 2 & 1 & 50 & $50 \pm 50$ & $0-100$ & 2 & 2 & 100 & $5 \pm 1$ & $4-6$ \\
\hline Xyleborus volvulus & 97 & 2 & 2 & $0.4 \pm 0.3$ & $0-20$ & 53 & 10 & 19 & $30 \pm 22$ & $0-1140$ \\
\hline Xylosandrus crassiusculus & 75 & 0 & 0 & 0 & 0 & 24 & 1 & 4 & $15 \pm 15$ & $0-360$ \\
\hline Xyleborinus gracilis & 3 & 0 & 0 & 0 & 0 & 10 & 0 & 0 & 0 & 0 \\
\hline Xyleborinus saxeseni у & 172 & 4 & 2 & $3 \pm 2$ & $0-200$ & 51 & 0 & 0 & 0 & 0 \\
\hline Totals/means & 413 & 8 & 2 & & & 161 & & 11 & & \\
\hline
\end{tabular}

$\mathrm{x}$ Recovery of Raffaelea lauricola from individuals of different species, as described by Carrillo et al. (2014). $\mathrm{n}=$ number of individuals that were assayed, $\mathrm{CFU}=$ colony forming unit of Raffaelea lauricola on a semi-selective medium, and SEM = standard error of the mean.

y In olfactometer assays, Xyleborus glabratus was attracted to Raffaelea lauricola, Xyleborus ferrugineus did not respond, and Xylosandrus crassiusculus and Xyleborinus saxeseni were repelled (Hulcr et al. 2011).

${ }^{\mathrm{z}}$ Xyleborus glabratus has not been recovered during recent surveys in laurel wilt-affected commercial avocado groves in Florida (see Table 2). 
That Xyleborinus saxesenii and Xylosandrus crassiusculus rarely carry $R$. lauricola corresponds with previous indications that they are repelled by the fungus. In olfactometer assays, Hulcr et al. (2011) determined that adult females of these species avoided cultures (volatiles) of the pathogen. Interestingly, another beetle that carried the pathogen more frequently, Xyleborus ferrugineus, had a net nonresponse (was repelled about as often as it was attracted; 156 vs. $132, P=0.16$ ), whereas $X$. glabratus was attracted to $R$. lauricola (in 54 of 84 assays, $P=0.004$ ) (Hulcr et al. 2011). X. glabratus responded synergistically to volatiles from their symbiotic fungi and host plant volatiles, compared to volatiles of the fungus or host plant alone (Kuhns et al. 2014). Infection of redbay with $R$. lauricola increased attractiveness of the host to X. glabratus (Martini and Stelinski, unpublished), which may enhance the spread of laurel wilt, as has been shown for other plant diseases with insect vectors (Mann et al. 2012). Recently, Martini et al. (2016) demonstrated that pathogeninduced manipulation of vector behavior can be disrupted. This semiochemical-based strategy is being investigated for the management of laurel wilt.

Understanding how different ambrosia beetles respond to $R$. lauricola and other microbes that they encounter in trees (e.g., other ambrosia beetle symbionts and avocado endophytes) could help identify vectors of the pathogen. Whether a beetle avoids, ignores, or is attracted to R. lauricola may impact whether it is a factor in the epidemiology of this disease on avocado. Similarly, determining whether and how the symbiotic fungus manipulates volatile release from host trees to affect behavior of the vector is significant. How do common species that are repelled by $R$. lauricola, such as Xyleborinus saxesenii, avoid the pathogen in trees that are affected by laurel wilt, and what do different beetle species farm in their natal galleries in laurel wilt-affected avocado trees? Do repelled species weed $R$. lauricola out of their gardens or do their symbionts inhibit its growth? Are beetles that are not repelled by the fungus able to cultivate it and utilize it as a food source, and does $R$. lauricola directly or indirectly manipulate the behavior of X. glabratus or other Xyleborus species interspecifically? The extent to which these are active decisions or passive functions of the vector $x$ microbial symbiont interaction is generally unknown. Kostovik et al. (2015) recently demonstrated that functionally and taxonomically distinct symbioses could be dictated by the type of mycangium that a given species possessed. Thus, the apparent preferential association between $R$. lauricola and Xyleborus congeners may reflect a conducive environment in that genus' mandibular mycangia, in addition to an innate attraction to the fungus (Ploetz et al. 2017a).

The identity of vectors of $R$. lauricola in avocado orchards and information on their reproductive potential, seasonality, and flight behavior are needed. A current working hypothesis is that ambrosia beetle species other than X. glabratus transmit $R$. lauricola to avocado, but very inefficiently. Once the pathogen infects a tree it moves rapidly throughout the xylem and to adjacent trees via interconnecting roots, in a manner similar to Dutch elm disease, caused by Ophiostoma spp., and oak wilt, caused by Ceratocystis fagacearum (Sinclair and Lyon 2005). Understanding which beetle species disseminate the pathogen to healthy trees and the circumstances under which these interactions occur will be critical to the development of strategies to keep unaffected avocado groves free of the disease. Also, understanding the flight capacity of vectors will be critical. Initial laboratory investigations suggest that females of different Xyleborus species are capable of many kilometers of continuous flight without wind assistance (Stelinski et al., unpublished). Explorations have only begun on the physiological limits of, and the impact of the symbiont-vector interaction on, their flight capacity.

The primary vector of $R$. lauricola in natural areas is X. glabratus (Carrillo et al. 2012; Hanula et al. 2008; Mayfield and Hanula 2012). Most studies on the life history of this beetle have been conducted in large stands of redbay or swamp bay. In redbay stands in north Florida, adults were active throughout the year; they were trapped in 
two peaks during March through April and October, and in the greatest numbers between 1600 and $1800 \mathrm{~h}$ and 35 to $100 \mathrm{~cm}$ above the ground (Brar et al. 2012).

Mayfield et al. (2008) determined that X. glabratus bored into, and transmitted $R$. lauricola to, potted avocado trees in no-choice tests. Peña et al. (2012) reported similar results for avocado cultivars that were not screened by Mayfield et al. (2008), and that X. glabratus bored into wood (detached bolts) of other New World species in the Lauraceae. In natural areas in central Florida, Kendra et al. (2011a, 2014a) found that volatiles from avocado wood were attractive to dispersing females of $X$. glabratus (Suppl. Fig. 2). The emissions of four sesquiterpenes - $\alpha$-copaene, $\alpha$-cubebene, $\alpha-$ humulene, and calamenene-was positively correlated with field captures. Brar et al. (2013) determined that $X$. glabratus developed at comparable rates in logs of avocado, redbay, and swamp bay, but that fewer progeny were produced in avocado. Thus, low numbers of $X$. glabratus that have been detected in avocado orchards may be due to avocado being a poor reproductive host.

Carrillo et al. (2014) reported that six and two species other than X. glabratus transmitted $R$. lauricola to potted redbay and avocado trees, respectively, and that laurel wilt developed in six and one of the interactions (Fig. 7). Given the rarity of $X$. glabratus in laurel wilt-affected avocado orchards and the ability of other ambrosia beetle species to harbor and transmit the pathogen, it seems probable that other species are capable of spreading $R$. lauricola in commercial settings. Other species could be significant factors in the epidemic on this crop, and might help $R$. lauricola expand its host range (Ploetz et al. 2013), as they usually have broader host ranges than X. glabratus (Carrillo et al. 2014; Hulcr and Lou 2013).

Rapid spread of laurel wilt in the southeastern United States has been associated with populations of susceptible host species (mainly redbay) and an efficient vector, $X$. glabratus. Spread may have also been exacerbated by the pathogen's promiscuity among different ambrosia beetle species, as noted above. Where redbay was a major component of communities, significant mortality developed within a few years of the onset of an epidemic (Er et al. 2013; Koch and Smith 2008). Compared to natural environments, a different pattern of spread has been evident in commercial avocado

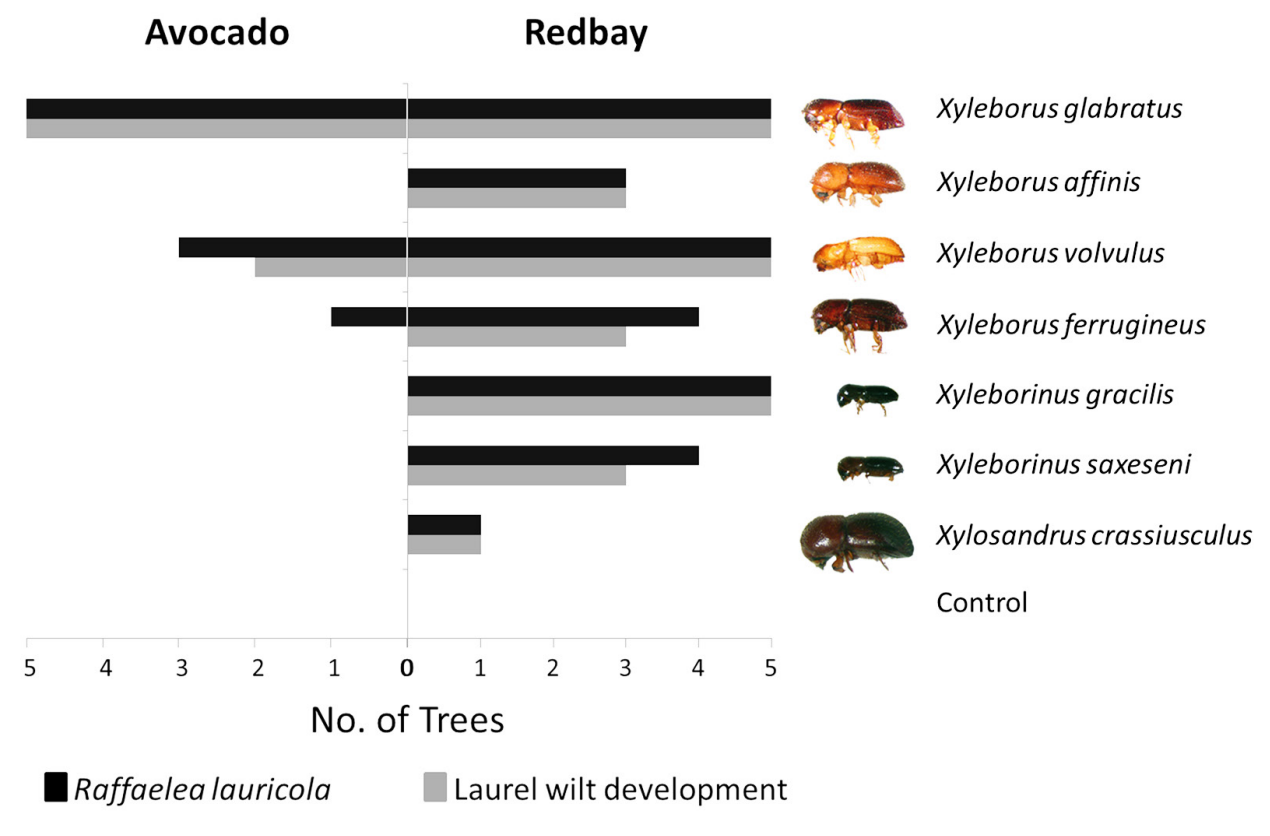

FIGURE 7

Transmission of Raffaelea lauricola to, and the development of laurel wilt in, healthy avocado and redbay trees confronted with seven species of ambrosia beetles under no-choice conditions. Five trees of each host tree were tested with each species of beetle. 
orchards. In the latter settings, high densities of this host are planted in rows in which root grafting occurs among adjacent trees, as shown previously by the movement of herbicides and another avocado pathogen, Avocado sunblotch viroid (ASBVd) (Ploetz et al. 2012b; Dann et al. 2013). Typically, laurel wilt develops initially on single trees that decline rapidly. If these trees and their associated stumps are not removed soon after detection, secondary spread occurs both to new foci within an orchard and to adjacent trees (Suppl. Figs. 2 and 3). New foci are thought to result from the activity of beetle vectors, but spread to adjacent trees in a focus is probably due to root-graft transmission of the pathogen because: (i) roots are infected by $R$. lauricola in trees that are naturally affected by laurel wilt; (ii) foci expand rapidly in avocado orchards before vectors could propagate and disseminate $R$. lauricola to surrounding trees; and (iii) prompt treatment of adjacent trees with fungicides impedes spread.

Size influences the order in which trees are affected by laurel wilt. Large native host trees are impacted first (Fraedrich et al. 2008; Kendra et al. 2013) (Fig. 8) owing to their greater attraction of $X$. glabratus due to visual cues (Mayfield and Brownie 2013) and higher content of $\alpha$-copaene (Niogret et al. 2013). Small trees are less apt to be attacked and may escape infection.

Biological invasion models predict that both host density and host clustering influence disease dynamics. These predictions were tested with data for laurel wilt outbreaks in natural areas in the southeastern United States (Er et al. 2013). Considering all hosts, the association of host density with disease spread was non-monotonic, with greater spread at intermediate host density. However, when only hosts with large stem diameters were considered, the correlation was positive and there was a density threshold for invasion. Environmental factors associated with laurel wilt dynamics included daily minimum temperature, daily precipitation, and soil organic matter content. Similar analyses have not been conducted for avocado.

Artificial inoculations of different host tree species with $R$. lauricola demonstrate that even small trees (i.e., those that might escape vector-mediated infection in nature) succumb to the disease (Fraedrich 2008; Fraedrich et al. 2009, 2011; Hughes et al. 2011, 2012, 2013, 2014; Ploetz and Konkol 2013; Riggins et al. 2011; Smith et al. 2009a, 2009b). However, in avocado studies in the absence of a vector, larger trees were also more susceptible (Suppl. Fig. 5) (Ploetz et al. 2012b). Latent infection of artificially inoculated avocado is uncommon, as R. lauricola is almost always isolated on microbiological media or detected via qPCR only from symptomatic sapwood.

Other possible avenues of infection have been studied experimentally. Mechanical transmission of the pathogen was only possible with artificially infested handsaws on potted plants; the pathogen did not survive on circular saws that are used to prune avocado trees in commercial groves owing, perhaps, to the high heat that was generated on these blades during use (Beckman 2012). Seed and scion transmission of $R$. lauricola have also been discounted. Potted, fruit-bearing trees were artificially inoculated with $R$. lauricola and plants were systemically colonized by the fungus, but in no instance did infection
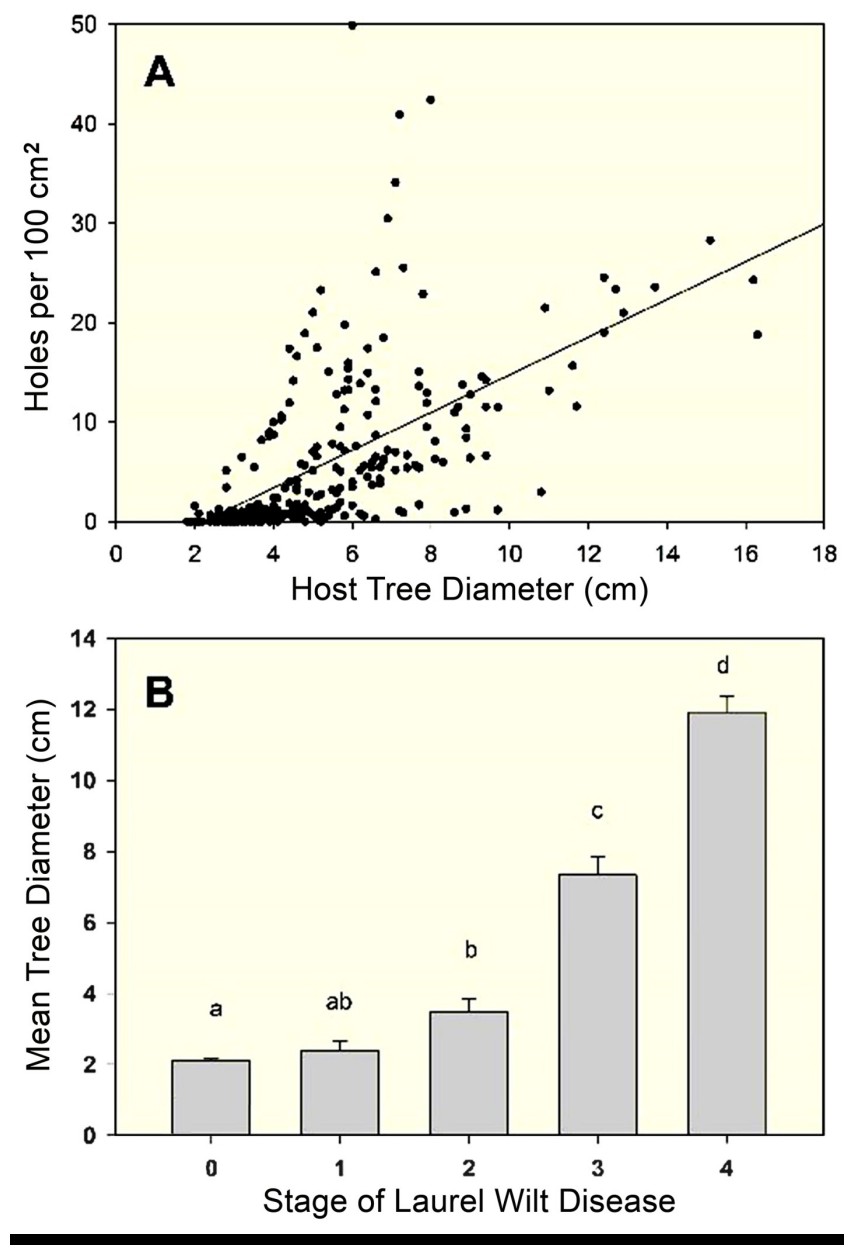

\section{FIGURE 8}

Relationships among host tree diameter, site of $X$. glabratus attack, and stage of laurel wilt development: (A) number of beetle entrance holes (per $100 \mathrm{~cm}^{2}$ ) versus the trunk/branch diameter of host swamp bay trees, Persea palustris $(\mathrm{N}=280)$, and (B) mean diameter of swamp bay trees and corresponding stage of laurel wilt development, where $0=$ asymptomatic, $1=$ wilted green to copper leaves $(<1$ year after symptom initiation), $2=$ gray leaves $(\sim 1$ year $), 3=$ no leaves $(\sim 2$ year $)$, and $4=$ fallen tree $(\sim 3$ year $)(N=830)$. 
progress further than the hilum of fruit (87 fruit and their associated pedicles) (Ploetz et al. 2012a). And when scions from artificially infected trees were used as grafting material, they did not establish on recipient rootstocks (Ploetz et al., unpublished). Thus, it appears that $R$. lauricola typically infects avocado only via ambrosia beetle vectors and interconnecting root grafts.

\section{Monitoring and Detection}

Early detection of laurel wilt, or R. lauricola-infected trees before they develop symptoms, is critical to the containment of laurel wilt and the success of disease management efforts in avocado orchards. Monitoring potential vectors in the avocado system is currently inefficient, and therefore not useful for predicting the threat of this disease in a given orchard.

Extensive trapping efforts that target $X$. glabratus are in place in commercial avocado orchards (Carrillo, unpublished). Initial studies that used manuka, phoebe and cubeb oil lures (Hanula et al. 2014; Kendra el al. 2012, 2014b) detected only four individuals of X. glabratus from 2012 to 2014 (Carrillo and Kendra, unpublished). Recently, with $\alpha$-copaene lures that detect low numbers of $X$. glabratus more efficiently (Kendra et al. 2016), the species was detected four times in avocado orchards in 2015 and twice in 2016 (Carrillo and Kendra, unpublished). In the future, $\alpha$-copaene lures could be important tools for examining the role of $X$. glabratus in the laurel wilt epidemic. Although specific attractants for other potential vectors are not available, $\sim 300,000$ ambrosia beetles have been trapped using ethanol lures (Miller and Rabaglia 2009) and various essential oil lures in avocado orchards since the beginning of the epidemic (Carrillo, unpublished; Kendra, unpublished). Thus, even though trapping these insects is inefficient, the available traps enable research on their relative abundance in avocado orchards and whether a given species carries $R$. lauricola. Current research focuses on detecting $X$. glabratus and other species that carry $R$. lauricola in commercial avocado settings.

Given the potentially confusing symptoms of laurel wilt compared to those associated with other biotic and abiotic factors (see II. Symptoms), the presence of $R$. lauricola should be confirmed when the disease is diagnosed for the first time in a given area or orchard. PCR amplification of ribosomal small-subunit DNA enabled detection of $0.0001 \mathrm{ng}$ of DNA of $R$. lauricola (Dreaden et al. 2008). This approach was suitable for some quantitative PCR applications, but was not taxon-specific, as an unidentified Raffaelea species was also identified as $R$. lauricola with this method (Dreaden 2014). The unidentified Raffaelea species, recently described as R. aguacate sp. nov. (Simmons et al. 2016), is not pathogenic to avocado, redbay, or swamp bay (Dreaden et al. 2016). Notably, another method that utilizes ribosomal large-subunit DNA (Jeyaprakash et al. 2014) may also not distinguish $R$. aguacate from $R$. lauricola (Dreaden et al. 2014). Recently, genomic sequencing of $R$. lauricola identified two simple-sequence repeat (SSR) loci that were used to develop a taxon-specific assay (Dreaden et al. 2014). PCR primers that were designed to amplify these loci did not amplify host DNA or DNA from related fungal taxa, including $R$. aguacate. The new SSR-based assay has a detection limit of $0.1 \mathrm{ng}$ of $R$. lauricola DNA, and is compatible with traditional and real-time PCR. Its reliability was confirmed in four different labs, but it could not be used to directly detect the pathogen in wood.

Visible near-infrared spectroscopy was tested for the nondestructive detection of laurel wilt on avocado (Sankaran et al. 2012). Classification studies were conducted with visible near-infrared spectra of asymptomatic and symptomatic leaves from plants artificially infected with $R$. lauricola, as well as leaves from noninfected freeze-damaged and healthy plants (Fig. 9). Scores from principal component analyses were used as input features in four classifiers: linear discriminant analysis; quadratic discriminant analysis (QDA); Naïve-Bayes classifier; and bagged decision 


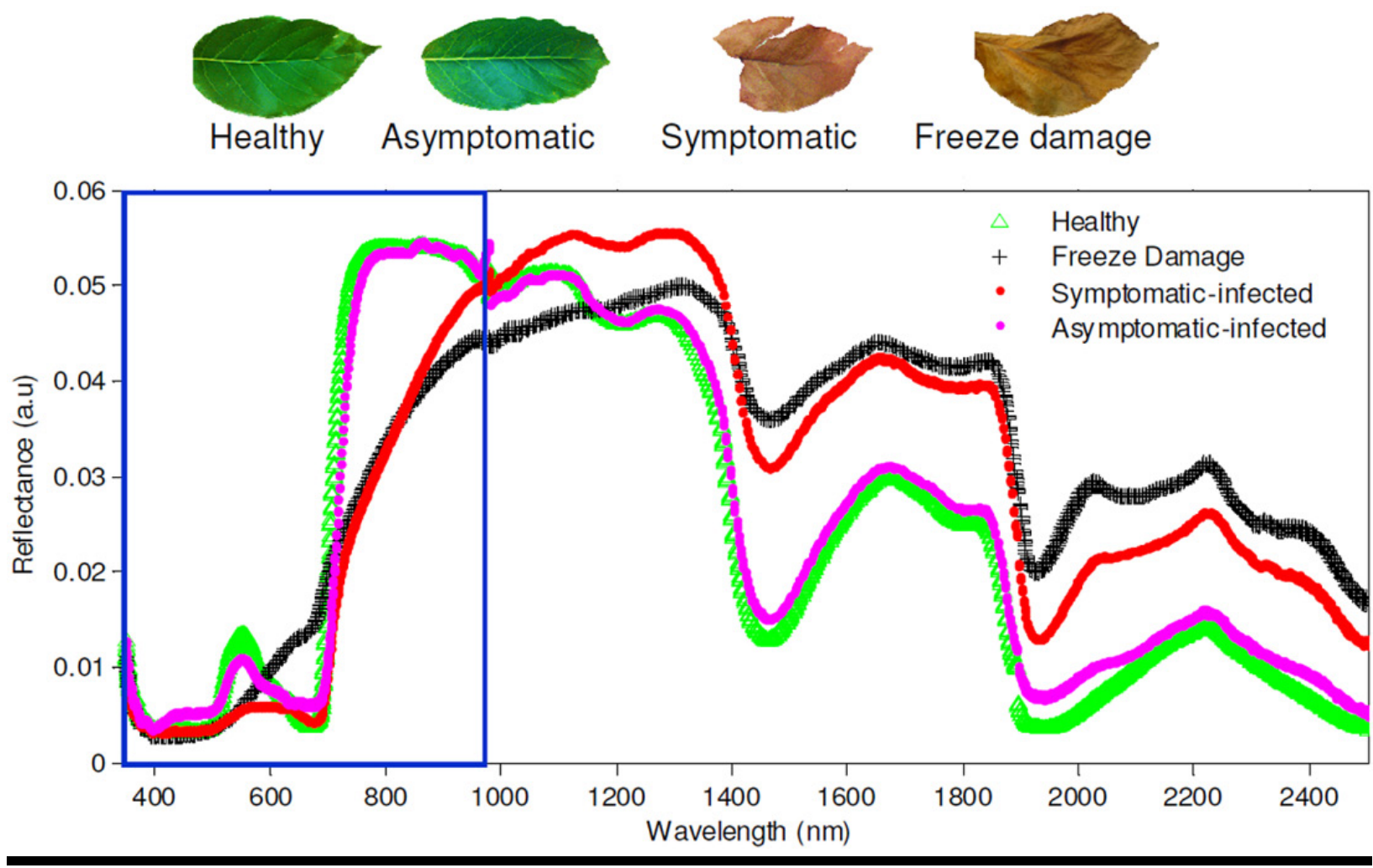

\section{FIGURE 9}

Representative leaves from healthy, Raffaelea lauricola-infected (asymptomatic and symptomatic), and freeze-damaged avocado plants. Visible near-infrared reflectance spectra representing each category of leaves are shown.

trees (BDT). All of the classifiers were able to discriminate leaves from plants with laurel wilt from freeze-damaged leaves. False negatives were primarily for asymptomatic leaves from infected plants that were classified as healthy.

In subsequent work, spectral data were used to distinguish healthy, laurel wiltaffected, and Phytophthora root rot-affected avocado trees (de Castro et al. 2015a) (Suppl. Fig. 6). With a modified camera, spectral images were taken during helicopter surveys of commercial avocado orchards (de Castro et al. 2015b). RmodGB digital data were used to calculate vegetation indices (VIs), band ratios, and VI combinations for healthy and laurel wilt-affected trees. Significant differences were observed in all vegetation indices calculated among laurel wilt affected and healthy trees, although the best results were achieved with Excess Red (ExR), (Red-Green), and Combination 1 (COMB1). These results were used to modify a MCA-6 Tetracam camera with different spectral filters $(580$ to $10 \mathrm{~nm}, 650$ to $10 \mathrm{~nm}, 740$ to $10 \mathrm{~nm}, 750$ to $10 \mathrm{~nm}$, 760 to $10 \mathrm{~nm}$ and 850 to $40 \mathrm{~nm}$ ), which was then used to take multispectral images of avocado trees at early, intermediate, and late stages of laurel wilt development at altitudes of 180, 250, and $300 \mathrm{~m}$ (de Castro et al. 2015a). At an ideal altitude of 250 $\mathrm{m}$, optimum VIs were calculated using any of the bands related to Redge (740 and $750 \mathrm{~nm}$ ) or NIR regions (760 and $850 \mathrm{~nm}$ ). An algorithm that is based on a four-class system (healthy trees, and those at early, intermediate, and late stages of laurel wilt development) is needed to develop an affordable spectral-based detection system for this disease (de Castro et al. 2015a).

\section{Response}

To date, there are no governmental regulations in place that indicate how affected avocado trees should be handled and where infested materials from such trees should be disposed. In the absence of such regulations, it is recommended that affected avocado trees be uprooted and the wood from affected trees be burned or chipped 
immediately. Wood chips should be spread out and treated with an approved insecticide. The latter activities would depend on local burning regulations and what is labeled for avocado. Recently, an ordinance was proposed in Miami-Dade Co. that required owners of laurel-wilt-affected orchards to dispose of affected trees in a timely manner or risk assessment of a tax lien.

\section{Permits and Regulatory Issues}

As of 21 May 2010, firewood could not be moved more than 50 miles from its source in the state of Florida and no firewood or unprocessed wood products could be moved into Miami-Dade Co. from other areas (see revised rule on Movement of Regulated Articles, 5B-65.005. https://www.flrules.org/gateway/readFile.asp?sid=3\& $\underline{\text { tid }=8683166 \& \text { type }=2 \& \text { file }=5 \mathrm{~B}-65.005 . \mathrm{htm})}$. The new restrictions should help mitigate the unnatural spread of laurel wilt in Florida.

The Florida Division of Forestry, in cooperation with the University of Florida IFAS, developed a certification program for Florida Pile Burners in 2005 and 2006. In 2009, the Florida Department of Agriculture amended the open burning rules and regulations to include the pile burner certification program. Florida Administrative Code (FAC) 5I-2 outlines the steps necessary to become certified and what is necessary to keep that certification. The rule states that a pile burner maintains their certification if they can show that they have used their certified burn number at least five times in the previous five years. In Miami-Dade Co., FL, burn permits can be expedited for destroying laurel-wilt affected trees in commercial production areas. The ability to burn affected trees in residential areas in Florida and elsewhere will depend on ordinances in the specific municipality.

\section{Economic Impacts}

Avocado is a subtropical/tropical tree. Depending on the cultivars that are grown, which vary considerably in their cold-tolerance, the crop is grown commercially from USDA Hardiness Zone 10 to 11, with moderate urban production of some cultivars occurring into Zone 9. Commercial avocado production is valued at $\$ 35$ million per year (wholesale crop value) in Florida (Evans et al. 2010; Evans and Ballen 2015) and $\$ 375$ million per year in California (online figures from California Avocado Commission). In both states, as well as Hawaii and Texas, additional urban production occurs of an unspecified value.

Before laurel wilt impacted commercial avocado plantings in Florida, Evans et al. (2010) estimated that losses could range from \$27 to 54 million in the absence of effective control measures (50 to 100\% loss). Although effective fungicidal measures are now available, they are expensive. In addition to economic considerations (cost of implementation and the expected benefits, which include treatment efficacy), a practice's adoptability (i.e., the ease with which it can be incorporated into the grower's routine and the time and energy that are expended) should be considered.

Given the cultivars that are currently grown, and yields and prices that are obtained for fruit, some growers have determined that laurel wilt management is uneconomical (costs exceed expected benefits). When these growers are affected by the disease, it becomes increasingly difficult to maintain fruit production. Where little or no management is practiced (i.e., no scouting for laurel wilt development is conducted, laurel wilt-affected trees are not removed quickly and adequately, and fungicides are not applied to impede hotspots development), excessive and rapid loss of trees occurs (see Suppl. Figs. 3 and 4). 


\section{Mitigation and Disease Management}

The current strategy for managing laurel wilt in commercial avocado orchards entails prompt detection and destruction of newly affected trees by chipping, treatment of chipped debris with contact insecticides, and protecting surrounding, adjacent trees with macroinfused propiconazole (Tilt, Syngenta Crop Protection, Greensboro, NC) fungicide (which has emergency 18C registration) (= "hotspot" treatment) (Ploetz et al. 2017b).

Twenty-eight fungicides in 15 chemical groups and 10 fungicide groups, as defined by the Fungicide Resistance Action Committee (FRAC, 2016), have been tested for in-vitro inhibition of $R$. lauricola and reduced development of laurel wilt on avocado (Ploetz et al. 2011b; 2017b; unpublished). Demethylation inhibitors (DMIs; fenarimol, myclobutanil, propiconazole, prothioconazole, triadimenol, triadimefon, and triticonazole), quinone outside inhibitors (azoxystrobin, pyraclostrobin, and fluoxastrobin), and a quinone inside inhibitor (fluazinam) had the greatest impact on radial growth of $R$. lauricola (the concentration at which growth was reduced by $50 \%$ was $\geq 0.1 \mu \mathrm{g} / \mathrm{ml})$.

In greenhouse studies, the most inhibitory products in-vitro, plus thiabendazole and two products that were not tested in-vitro, flutriafol and a potassium salts mixture of phosphorus acid, were tested for disease suppression on artificially inoculated, potted avocado trees (Ploetz et al. 2011c). In general, soil drench applications of the above DMIs and thiabendazole, but not azoxystrobin, pyraclostrobin, fluazinam, or the phosphorus acid salt provided significant control of disease $(P<0.05)$. Topical branch or trunk applications of propiconazole, and triadimenol in $2 \%$ Pentrabark, a bark-penetrating surfactant, were also effective at lower rates than were used in drench applications. Comparable levels of disease suppression were achieved when propiconazole was applied at $11 \%$ of the rates that were used in soil drenches (Suppl. Fig. 7). Unfortunately, minor concentrations of propiconazole were detected in the xylem of branches of field-grown trees that were larger than approximately 2 to $3 \mathrm{~cm}$ in diameter, probably due to thick(er) bark impeding penetration and uptake (Ploetz et al. 2017b).

In a recent series of studies in Florida, fungicidal management of laurel wilt was tested in field-grown avocado trees. Trees were treated 2 to 4 weeks prior to being artificially inoculated with $R$. lauricola (Crane et al. 2016; Ploetz et al. 2017b). In general, the efficacy of propiconazole was confirmed, although trees were not protected for more than a year in any of the experiments. Although a need for annual retreatment was indicated by the results, it should be noted that minute amounts of the fungicide were detected in fruit (far less than the maximum $2 \mathrm{ppm}$ set by the EPA for food residues), regardless of the application method used. Thus, fungicides could be used safely on fruit-bearing trees.

In general, macroinfusion of Propiconazole Pro, an injectable formulation of propiconazole, provided the best protection, although Tilt was also effective if it was applied via macroinfusion (Crane et al. 2016; Ploetz et al. 2017b). Macroinfusion applies large volumes of dilute fungicide to the flare roots of trees (Blaedow et al. 2010; Mayfield et al. 2008; Stipes 2000; Tattar 2007), and in avocado appears to be the most effective way to move fungistatic levels of fungicide to the infection court for $R$. lauricola, the xylem. Unfortunately, macroinfusion is labor intensive and cannot be used to treat entire orchards due to its expense (Ploetz et al. 2011c). A critical need exists for enhanced application measures, improved formulations of fungicides that would have better mobility in trees, and longer retention times for injected products (Ploetz et al. 2017b). Protecting trees in the field with fungicides is an ongoing challenge.

Due to the importance of $X$. glabratus in natural environments, it was expected that large numbers would attack avocado trees when commercial production areas 
were affected by laurel wilt. To prepare for this anticipated invasion, extensive efforts were made to develop integrated management tactics for the insect. Peña et al. (2011) and Carrillo et al. (2013) studied the efficacy of more than 20 systemic (imidacloprid, emamectin benzoate, cyazypyr, flupyradifurone + propylen carbonate, spirotetramat, chlorantraniliprole, and sulfoxaflor) and contact (bifenthrin, fenpropathrin, zcypermethrin + bifenthrin, permethrin, lambda-cyhalothrin + thiamethoxam, malathion, chlorpyrifos, carbaryl, endosulfan, novaluron, and difubenzuron) insecticides. Systemic insecticides applied as a drench did not control X. glabratus and when products were injected only emamectin benzoate provided partial control of this beetle. Among contact insecticides, z-cypermethrin + bifenthrin, bifenthin, fenpropathrin, and malathion significantly reduced the numbers of beetles that bored into avocado logs, but no treatment completely stopped boring by X. glabratus. Fenpropathrin, malathion, and bifenthrin are registered for use in avocado and an emergency exemption (section 18) is in place to use z-cypermethrin + bifenthrin on non-bearing trees. In the field, the above insecticide active ingredients are also active against other ambrosia beetles that are known to transport $R$. lauricola (Carrillo, unpublished). Once key vectors in the avocado system are identified, chemical control tactics would need to be redirected to target these species.

Three commercial strains of entomopathogenic fungi (two strains of Isaria fumosorosea (Ifr 3581 and PFR), and strain GHA of Beauveria bassiana) were evaluated recently as biological control agents of X. glabratus (Carrillo et al. 2015). Although the strain of B. bassiana killed X. glabratus females faster than either strain of I. fumosorosea, infection by none of the entomopathogens prevented X. glabratus from boring into avocado logs; presumably, infected individuals would still infest intact trees with $R$. lauricola if they bored into intact trees.

As noted above for the fungicide studies, insecticide and biopesticide efficacy are constrained by the inherent difficulty of moving products to where they are needed, the host's xylem (ambrosia beetle breeding sites). An additional consideration for vector management is that it would need to be highly effective in order to impact laurel wilt development, as a single interaction of a $R$. lauricola-infested ambrosia beetle with a healthy avocado tree may be all that is needed to initiate a lethal infection. Whether treatments that would be less than totally effective against vectors would still have an impact on laurel wilt development needs to be determined.

Persea americana is divided into Mexican (M), Guatemalan (G), and West Indian (WI) (a.k.a. Lowland or Antillean) botanical races (Lahav and Lavi 2013). From 2010 to 2012, 24 commercial avocado cultivars of various racial backgrounds were screened for response to laurel wilt in field studies (Ploetz et al. 2012b). Although resistant cultivars were not identified, $\mathrm{G}$ and $\mathrm{M} \times \mathrm{G}$ hybrid cultivars were more tolerant than WI cultivars, such as 'Simmonds,' which comprises $35 \%$ of the commercial production in Florida and has been used as a standard susceptible genotype in different studies. Mechanisms that were associated with the range of responses that were evident in these trials were not examined. For example, the extent to which xylem function and other factors may have influenced disease development in the different cultivars was not assessed. To date, mature trees of 28 avocado cultivars (nine WI, $14 \mathrm{WI} \times \mathrm{G}$, two of unknown parentage, and one each of $\mathrm{G}, \mathrm{G} \times \mathrm{M} \times \mathrm{WI}$, and $\mathrm{G} \times \mathrm{M}$ cultivar) have been killed by laurel wilt in the CAPA (Crane et al. 2015).

Since there are no effective measures for organic producers, host resistance might be the only hope for such growers. However, developing new scion genotypes that resist laurel wilt and also possess desirable organoleptic and horticultural traits would be a long-term process. Current research examines the impact of different rootstock and scion combinations on xylem attributes and laurel wilt susceptibility. In other crops, rootstocks can significantly influence the grafted scion. For example, different avocado rootstocks affected post-harvest disease development on fruit of 'Hass' 
(Willingham et al. 2006), and xylem sap flow rates in 'Hass' scions (Fassio et al. 2009).

Commercial avocado scions are traditionally grafted on seedling WI rootstocks in Florida, which are quite variable due to their hybrid nature (avocado preferentially outcrosses). Given the positive relationship between xylem sap flow rates and laurel wilt susceptibility (Fig. 10), the influences that rootstocks have on scions, and the variable laurel wilt responses that have been observed when clonal avocado scions are grafted on seedling rootstocks (note variation in Suppl. Fig. 5), Ploetz et al. (2015) proposed that clonal avocado rootstocks could influence the susceptibility of a given scion to laurel wilt; they suggested that less susceptible $\mathrm{G}$ and $\mathrm{M}$ genotypes would reduce the susceptibility of WI scions when used as rootstocks, and that clonal, rather than seedling, rootstocks should enable a more consistent scion response.

\section{Infrastructure and Experts}

\section{PATHOLOGY, MYCOLOGY}

Tyler Dreaden, Research Pathologist, USDA-Forest Service, Lexington, KY, conducted research on the molecular characterization of ambrosia beetle symbionts and the detection of $R$. lauricola as a graduate student at University of Florida (UF). He continues work on laurel wilt in his current position.

Stephen Fraedrich, Research Pathologist, Forest Service, Athens, GA, was the first to identify laurel wilt. He has documented its impact on native lauraceous hosts, examined its host range, and investigated vector relationships with $X$. glabratus and other ambrosia beetles.

Marc Hughes, post-doctoral researcher, University of Hawaii at Manoa, Hilo, HI, has considerable experience with laurel wilt on native trees, especially redbay. He led the revision of the Recovery Plan for laurel wilt on native Lauraceae published in 2015.

Randy Ploetz, Professor of Plant Pathology, UF, Homestead, is an authority on the diagnosis and management of tropical fruit diseases, including those that impact avocado. He currently researches host responses and resistance to laurel wilt, laurel wilt management, and the host range and alternative vectors of $R$. lauricola.

\section{ENTOMOLOGY, VECTOR RELATIONS}

Daniel Carrillo, Assistant Professor of Entomology, Entomology and Nematology Department, UF, Tropical Research and Education Center, Homestead, is an expert in Tropical Fruit Entomology and studies the ambrosia beetles associated with the laurel wilt epidemic in South Florida.

Jiri Hulcr, Assistant Professor of Forest Entomology, School of Forest Resources and Conservation, UF, Gainesville, is an expert on ambrosia beetles, their symbionts, and their host interactions.

Paul Kendra, Research Entomologist, USDA-ARS Subtropical Horticulture Research Station, Miami, conducts research on host-based attractants for Xyleborus glabratus and lure development.

Bud Mayfield, Research Entomologist, USDA Forest Service, Southern Research Station, Asheville, NC, has considerable experience monitoring the spread of $X$. glabratus and laurel wilt, and assessing the attractiveness of avocado and other hosts to $X$. glabratus.

Lukasz Stelinski, Associate Professor at the Entomology, Entomology, and Nematology Department, UF, Citrus Research and Education Center, Lake Alfred, is a chemical ecologist and an expert in insect-vectored plant diseases, in particular Huanglongbing of citrus. 


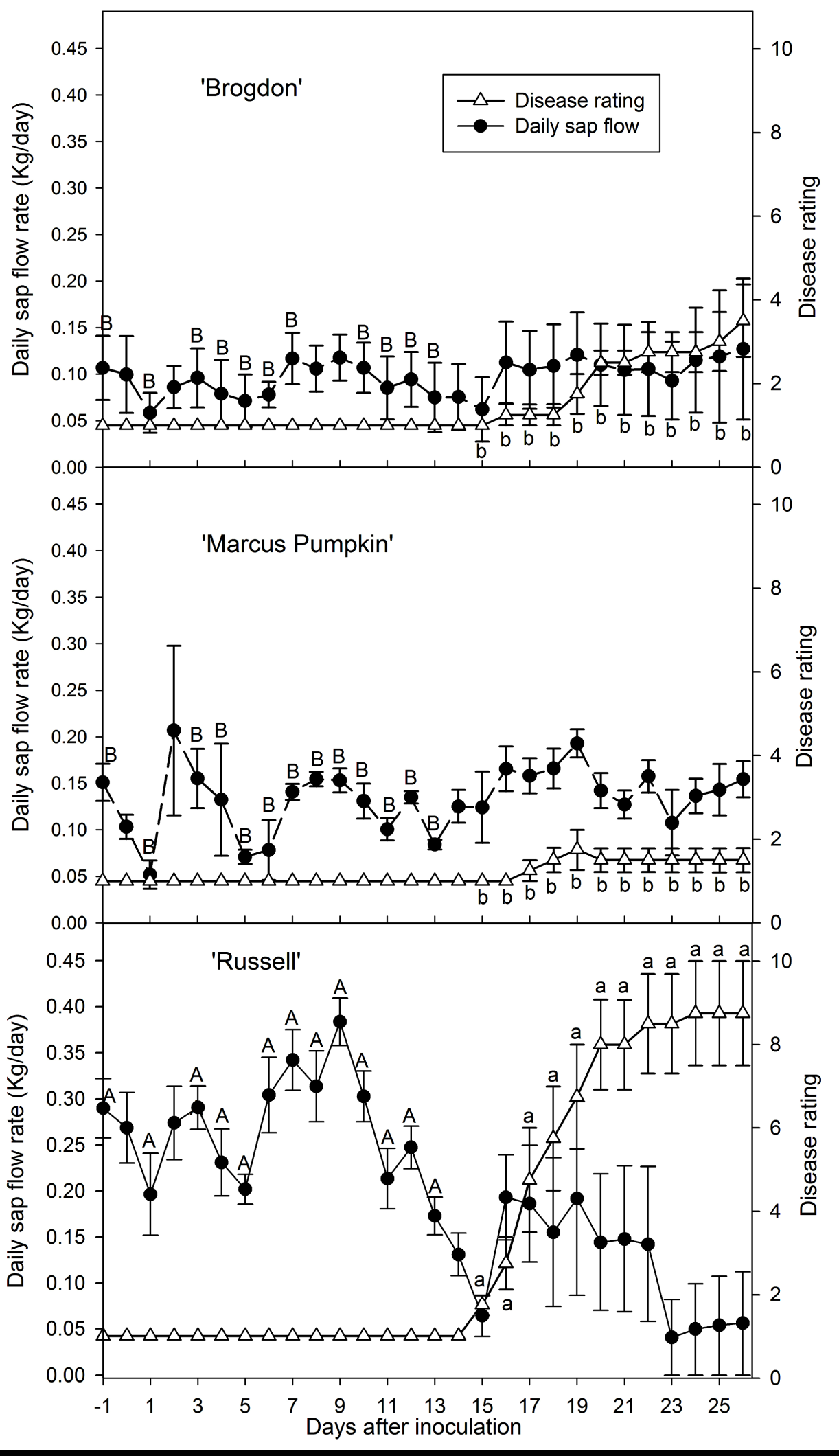

FIGURE 10

Mean daily xylem sap flow and visual disease rating for 'Brogdon' ( $M \times G \times W I$ hybrid) 'Marcus Pumpkin' (G) and 'Russell'(WI) avocado trees inoculated with Raffaela lauricola. Different upper case letters indicate significant difference in xylem sap flow among cultivars and different lower case letters indicate significant differences in disease rating among cultivars according to a repeated measures ANOVA $(P<0.05)$. Absence of letters indicate no significant differences between cultivars $(P>0.05)$. Note significantly higher sap flow rates in laurel wilt susceptible 'Russell', compared to 'Brogdon' and 'Marcus Pumpkin'. 


\section{EXTENSION}

Jonathan Crane, Professor of Horticultural Science, UF, Tropical Research and Education Center, Homestead, is an expert on the production systems of tropical fruit crops including avocado. His extension program addresses the management of laurel wilt.

E. A. "Gilly" Evans, Professor of Food and Resource Economics, UF, Tropical Research and Education Center, Homestead, investigates the economic impact of laurel wilt and cost considerations for its management.

\section{ADMINISTRATION}

Julius Fajardo, Plant Pathologist, Office of Pest Management Policy, USDA, Washington, D.C.

\section{Research, Extension, and Education Priorities}

Cost-effective management of laurel wilt on avocado will require new information in several key areas. The ambrosia beetle species that are vectors of this pathogen (i.e., initiate infection in healthy trees as opposed to colonize diseased and dying trees) should be determined. The available evidence suggests that resident ambrosia beetles are vectors in the avocado pathosystem, but that they are inefficient. Little is known about the fundamental biology of these previously inoffensive species. Information on the reproductive potential, seasonality, and flight behavior of these species in avocado groves is needed, as it could provide essential insight into their roles in the development of this disease on this important host tree. To understand the role that these species play in the spread of laurel wilt, it may also be necessary to understand their responses to symbionts and endophytes that they would encounter in avocado trees.

The radical response of susceptible hosts to inoculation with $R$. lauricola is poorly understood. More information is needed for how the pathogen interacts with different host species and different avocado cultivars, as well as the fundamental mechanisms of transmission. Defining acquisition and inoculation periods, as well as latency and vector capacity, among the various species that transmit $R$. lauricola to avocado should improve insecticidal and cultural management practices for the vectors. Nothing is known about pathogen products that are produced in planta that impact disease development. Likewise, it is not clear whether there are differences in the extent and distribution of colonization by $R$. lauricola in tolerant and susceptible hosts, as was suggested by preliminary work (Fig. 5). For example, whether systemic colonization is associated with susceptibility and restricted development of the pathogen is associated with tolerance should be determined. Indirect effects of the pathogen on the vector via plant responses, as well as plant defense mechanisms against the vector, are also still poorly understood.

In response to stakeholder surveys, extension methods to inform and demonstrate management strategies for laurel wilt have shifted to provide more on-line content in the form of videos, PowerPoints, e-mail, and literature. Workshops, seminars, and field demonstrations of limited subject matter and of shorter duration are desired by stakeholders.

\section{Timeline for Recovery}

Approximately $2 \%$ of the commercial avocado trees in the CAPA have been lost to laurel wilt. Some producers of limited economic means have dropped out of the industry, and more may follow as the disease spreads. Nonetheless, producers that manage about $60 \%$ of the industry have replanted avocado in areas where mature trees have been killed by the disease. 
Resiliency factors that impact recovery:

- Multiple vectors may be involved. At best, our ability to manage vectors is incomplete, even in a local sense. Since the pathogen is thought to be successfully transmitted to avocado after a single interaction with a vector, management of laurel wilt via vector control will be difficult.

- The pathogen can colonize and quickly kill avocados, and focal spread of the disease by root graft transmission is rapid in avocado orchards. Reducing or eliminating focal spread is a great challenge.

- Substantial reservoirs of the pathogen and vector(s) exist in natural areas in affected and threatened avocado-production areas. Based on the available evidence, it appears that the reservoirs play an important role in laurel wilt establishment in a given area. Thus, development of effective management strategies for laurel wilt in natural ecosystems and residential landscapes adjacent to the CAPAs could complement management efforts within orchards. Local populations of native hosts (especially redbay and swamp bay) have been devastated by laurel wilt. However, the impact that decreased reservoir numbers will have on corresponding disease pressure in neighboring avocado productions areas is unclear.

\section{References}

Atkinson, T. H., Carrillo, D., Duncan, R. E., and Peña, J. E. 2013. Occurrence of Xyleborus bispinatus (Coleoptera: Curculionidae: Scolytinae) Eichhoff in southern Florida. Zootaxa 3669:96-100.

Barton, C., Bates, C., Cutrer, B., Eickwort, J., Harrington, S., Jenkins, D., McReynolds Stones, D., Reid, L. Riggins, J.J., and Trickel, R. 2016. Distribution of counties with laurel wilt disease by year of initial detection. http://www.fs.usda.gov/Internet/ FSE DOCUMENTS/fseprd513913.pdf

Batra, L. R. 1966. Ambrosia fungi: Extent of specificity to ambrosia beetles. Science 173:193-195.

Beckman, F. C. 2012. Laurel wilt: Assessing the risk of pruning tool transmission of Raffaelea lauricola. M.S. thesis. University of Florida, Gainesville.

Blaedow, R. A., Juzwik, J., and Barber, B. 2010. Propiconazole distribution and effects on Ceratocystis fagacearum survival in roots of treated red oaks. Phytopathology 100:979-985.

Brar, G. S., Capinera, J. L., Kendra, P. E., McLean, S., and Peña, J. E. 2013. Life cycle, development, and culture of Xyleborus glabratus (Coleoptera: Curculionidae: Scolytinae). Fla. Entomol. 96:1158-1167.

Brar, G. S., Capinera, J. L., McLean, S., Ploetz, R. C., and Peña, J. E. 2012. Effect of trap size, trap height and age of lure on sampling Xyleborus glabratus (Coleoptera: Curculionidae: Scolytinae), and its flight periodicity and seasonality. Fla. Entomol. 95:1003-1011.

Campbell, A. S., Ploetz, R. C., and Rollins, J. A. 2017. Comparing avocado, swamp bay, and camphortree as hosts of Raffaelea lauricola using a green fluorescent protein (GFP)-labeled strain of the pathogen. Phytopathology 107:70-74.

Carrillo, D., Crane, J. H., and Peña, J. E. 2013. Potential of contact insecticides to control Xyleborus glabratus (Coleoptera: Curculionidae), a vector of laurel wilt in avocados. J. Econ. Entomol. 106:2286-2295.

Carrillo, D., Duncan, R. E., and Peña, J. E. 2012. Ambrosia beetles (Coleoptera: Curculionidae: Scolytinae) that breed in avocado wood in Florida. Fla. Entomol. 95:573-579.

Carrillo, D., Duncan, R. E., Ploetz, J. N., Campbell, A., Ploetz, R. C., and Peña, J. E. 2014. Lateral transfer of a phytopathogenic symbiont among native and exotic ambrosia beetles. Plant Pathol. 63:54-62.

Carrillo, D., Dunlap, C. A., Avery, P. B., Navarrete, J., Duncan, R. E., Jackson, M. A., Behle, R. W., Cave, R. D., Crane, J., Rooney, A. P., and Peña, J. E. 2015. Entomopathogenic fungi as biological control agents for the vector of the laurel wilt disease, the redbay ambrosia beetle, Xyleborus glabratus (Coleoptera: Curculionidae). Biol. Control 81:44-50.

Crane, J. H., Evans, E. A., Carrillo, D., Ploetz, R. C., and Palmateer, A. J. 2015. The potential for laurel wilt to threaten avocado production is real. Pages 9-16 in: ACTAS: 
Proc. VIII Congreso Mundial de la Palta, Lima, Perú. Avocadosource.com, Hofshi Foundation, Fallbrook, CA.

Crane, J. H., Ploetz, R. C., White, T., Krogstad, G. C., Prosser, T., Konkol, J., and Wideman, R. 2016. Efficacy of three macroinfused fungicides to control laurel wilt on avocado in Martin and Brevard Counties. Proc. Fla. State Hort. Soc. 128:(In press).

de Castro, A. I., Ehsani, R., Ploetz, R., Crane, J. H., and Abdulridh, J. 2015a. Optimum spectral and geometric parameters for early detection of laurel wilt disease in avocado. Remote Sensing of Environment 171:33-44.

de Castro, A. I., Ehsani, R., Ploetz, R. C., Crane, J. H., and Buchanon, S. 2015b. Detection of laurel wilt disease in avocado using low altitude aerial imaging. PLoS ONE 10(4):e0124642. doi:10.1371/journal.pone.0124642

Dann, E., Ploetz, R. C., Pegg, K. G., and Coates, L. 2012. Diseases of avocado. Pages 380-422 in: The Avocado, 2nd Edn. B. Schaffer, B. Nigel Wolstenholme, and A. W. Whiley, eds. CABI, Wallingford, UK.

Dreaden, T. J. 2014. Detection methods and taxonomic clarifications for three emerging tree pathogens in Florida, Diplodia corticola, Diplodia quercivora, and Raffaelea lauricola. PhD thesis. University of Florida, Gainesville.

Dreaden, T. J., Campbell, A. S., Gonzalez-Benecke, C. A., Ploetz, R. C., and Smith, J. A. 2016. Response of swamp bay, Persea palustris, and redbay, P. borbonia, to Raffaelea spp. isolated from Xyleborus glabratus. For. Pathol. doi:10.1111/efp.12288

Dreaden, T. J., Davis, J. M., de Beer, W. Z., Ploetz, R. C., Soltis, P. S., Wingfield, M. J., and Smith, J. A. 2014a. Phylogeny of ambrosia beetle symbionts in the genus Raffaelea. Fungal Biol. doi:10.1016/j.funbio.2014.09.001.

Dreaden, T. J., Davis, J. M., Harmon, C. L., Ploetz, R. C., Palmateer, A. J., Soltis, P. S., and Smith, J. A. 2014b. Development of multilocus PCR assays for Raffaelea lauricola, causal agent of laurel wilt disease. Plant Dis. 98:379-383.

Dreaden, T. J., Smith, J. A., and Mayfield, A. E. 2008. Development of a real-time PCR assay for detection of the Raffaelea species causing laurel wilt disease. Phytopathology 98:S48.

Er, H.-L., Hughes, M., Smith, J., Pruett, G., Konkol, J., Ploetz, R., Marois, J., and van Bruggen, A. 2013. Epidemiological study on laurel wilt. Phytopathology 103(Suppl. 2):S2.40,

Evans, E. A., Crane, J. H., Hodges, A., and Osborne, J. L. 2010. Potential economic impact of laurel wilt disease on the Florida avocado industry. HortTechnology 20:234238.

Evans, E. A., and Ballen, F. H. 2015. An econonmetric demand model for Florida greenskin avocados. HortTechnology 25:405-411.

Fassio, C., Heath, R., Arpaia, M. L., and Castro, M. 2009. Sapflow in 'Hass' avocado trees on two clonal rootstocks in relation to xylem anatomy. Scientia Hort. 120:8-13.

Fraedrich, S. W. 2008. California laurel is susceptible to laurel wilt caused by Raffaelea lauricola. Plant Dis. 92:1469.

Fraedrich, S. W., Harrington, T. C., Bates, C. A., Johnson, J., Reid, L. S., Best, G. S., Leininger, T. D., and Hawkins, T. S. 2011. Susceptibility to laurel wilt and disease incidence in two rare plant species, pondberry and pondspice. Plant Dis. 95:10561062.

Fraedrich, S. W., Harrington, T. C., Rabaglia, R. J., Ulyshen, M. D., Mayfield, A. E., III, Hanula, J. L., Eickwort, J. M., and Miller, D. R. 2008. A fungal symbiont of the redbay ambrosia beetle causes a lethal wilt in redbay and other Lauraceae in the southeastern USA. Plant Dis. 92:215-224.

Gebhardt, H., Begerow, D., and Oberwinkler, F. 2004. Identification of the ambrosia fungus of Xyleborus monographus and X. dryographus (Coleoptera: Curculionidae, Scolytinae). Mycol. Prog. 3:95-102.

Griffiths, K. M., Derksen, A., and Smith, T. 2010. 2009 Florida CAPS Laurel Wilt Survey Annual Report. Publ. No. 2009-01-LW-03. Florida Div. of Plant Industry, Avon Park.

Haack, R. A. 2006. Exotic bark- and wood-boring Coleoptera in the United States: Recent establishments and interceptions. Can. J. For. Res. 36:269-288.

Hanula, J. L., Mayfield, A. E., III, Fraedrich, S. W., and Rabaglia, R. J. 2008. Biology and host associations of redbay ambrosia beetle (Coleoptera: Curculionidae: Scolytinae), exotic vector of laurel wilt killing redbay trees in the southeastern United States. J. Econ. Entomol. 101:1276-1286.

Harrington, T. C., Aghayeva, D. N., and Fraedrich, S. W. 2010. New combinations in Raffaelea, Ambrosiella, and Hyalorhinocladiela, and four new species from the redbay ambrosia beetle, Xyleborus glabratus. Mycotaxon 111:337-361.

Harrington, T. C., and Fraedrich, S. W. 2010. Quantification of propagules of the laurel wilt fungus and other mycangial fungi from the redbay ambrosia beetle, Xyleborus glabratus. Phytopathology 100:1118-1123. 
Harrington, T. C., Fraedrich, S. W., and Aghayeva, D. 2008. Raffaelea lauricola, a new ambrosia beetle symbiont and pathogen on the Lauraceae. Mycotaxon 102:399-404.

Harrington, T. C., Yun, H. Y., Lu, S. S., Goto, H., Aghayeva, D. N., and Fraedrich, S. W. 2011. Isolations from the redbay ambrosia beetle, Xyleborus glabratus, confirm that the laurel wilt pathogen, Raffaelea lauricola, originated in Asia. Mycologia 103:10281036.

Hughes, M. A. 2013. The evaluation of natural resistance to laurel wilt disease in redbay (Persea borbonia). Ph.D. thesis. Univ. of Florida, Gainesville.

Hughes, M. A., Brar, G., Ploetz, R. C., and Smith, J. A. 2013. Field and growth chamber inoculations demonstrate Persea indica as a newly recognized host for the laurel wilt pathogen, Raffaelea laurciola. Plant Health Prog. doi:10.1094/PHP-2013-0814-02-BR.

Hughes, M., Smith, J. A., Mayfield, A. E., Minno, M. C., and Shin, K. 2011. First report of laurel wilt disease caused by Raffaelea lauricola on pondspice in Florida. Plant Dis. 95:1588.

Hughes, M. A., Inch, S. A., Ploetz, R. C., Er, H. L., van Bruggen, A. H. C., and Smith, J. A. 2015a. Responses of swamp bay, Persea palustris, and avocado, Persea americana, to the laurel wilt pathogen, Raffaelea lauricola. For. Pathol. 45:111-119.

Hughes, M. A., Shin, K., Eickwort, J., and Smith, J. A. 2012. First report of laurel wilt disease caused by Raffaelea lauricola on silk bay in Florida. Plant Dis. 96:910.

Hughes, M. A., and Smith, J. A. 2014. Vegetative propagation of putatively laurel wiltresistant redbay (Persea borbonia). Native Plants 115:42-50.

Hughes, M. A., Smith, J. A., Ploetz, R. C., Kendra, P. E., Mayfield, A. E., III, Hanula, J. L., Hulcr, J., Stelinski, L. L., Cameron, S., Riggins, J. J., Carrillo, D., Rabaglia, R., Eickwort, J., and Pernas, T. 2015b. Recovery plan for laurel wilt on redbay and other forest species caused by Raffaelea lauricola and disseminated by Xyleborus glabratus. Plant Health Prog. 16:173-210.

Hulcr, J., and Dunn, R. R. 2011. The sudden emergence of pathogenicity in insect-fungus symbioses threatens naive forest ecosystems. Proc. Roy. Soc. B Sci. 278:2866-2873.

Hulcr, J., and Lou, Q.-Z. 2013. The redbay ambrosia beetle (Coleoptera: Curculionidae) prefers Lauraceae in its native range: Records from the Chinese national insect collection. Fla. Entomol. 96:1595-1596.

Hulcr, J., Mann, R., and Stelinski, L. L. 2011. The scent of a partner: Ambrosia beetles are attracted to volatiles from their fungal symbionts. J. Chem. Ecol. 37:1374-1377.

Inch, S. A., and Ploetz, R. C. 2012. Impact of laurel wilt, caused by Raffaelea lauricola, on xylem function in avocado. For. Pathol. 42:239-245.

Inch, S. A., Ploetz, R. C., Held, B., and Blanchette, R. 2012. Histological and anatomical responses in avocado, Persea americana, induced by the vascular wilt pathogen, Raffaelea lauricola. Botany 90:627-635.

Jeyaprakash, A., Davison, D. A., and Schubert, T. S. 2014. Molecular detection of the laurel wilt fungus, Raffaelea lauricola. Plant Dis. 98:559-564.

Kendra, P. E., Montgomery, W. S., Deyrup, M. A., and Wakarchuk, D. 2016. Improved lure for redbay ambrosia beetle developed by enrichment of $\alpha$-copaene content. J. Pest Sci. 89:427-438.

Kendra, P. E., Montgomery, W. S., Niogret, J., and Epsky, N. D. 2013. An uncertain future for American Lauraceae: A lethal threat from redbay ambrosia beetle and laurel wilt disease. Am J. Plant Sci. 4:727-738.

Kendra, P. E., Montgomery, W. S., Niogret, J., Peña, J. E., Capinera, J. L., Brar, G., Epsky, N. D., and Heath, R. R. 2011a. Attraction of the redbay ambrosia beetle, Xyleborus glabratus, to avocado, lychee, and essential oil lures. J. Chem. Ecol. 37:932-942.

Kendra, P. E., Montgomery, W. S., Niogret, J., Pruett, G. E., Mayfield A. E., III, MacKenzie, M., Deyrup, M. A., Bauchan, G. R., Ploetz, R. C., and Epsky, N. D. 2014a. North American Lauraceae: Terpenoid emissions, relative attraction and boring preferences of redbay ambrosia beetle, Xyleborus glabratus (Coleoptera: Curculionidae: Scolytinae). PLoS One 9:e102086.

Kendra, P. E., Montgomery, W. S., Niogret, J., Schnell, E. Q., Deyrup, M. A., and Epsky, N. D. 2014b. Evaluation of seven essential oils identifies cubeb oil as most effective attractant for detection of Xyleborus glabratus. J. Pest Sci. 87:681-689.

Kendra, P. E., Niogret, J., Montgomery, W. S., Sanchez, J. S., Deyrup, M. A., Pruett, G. E., Ploetz, R. C., Epsky, N. D., and Heath, R. R. 2012. Temporal analysis of sesquiterpene emissions from manuka and phoebe oil lures and efficacy for attraction of Xyleborus glabratus (Coleoptera: Curculionidae: Scolytinae). J. Econ. Entomol. 105:659-669.

Kendra, P. E., Sanchez, J. S., Montgomery, W. S., Okins, K. E., Niogret, J., Peña, J. E., Epsky, N. D., and Heath, R. R. 2011b. Diversity of Scolytinae (Coleoptera: Curculionidae) attracted to avocado, lychee, and essential oil lures. Fla. Entomol. 94:123-130. 
Klepzig, K. D., Adams, A. S., Handelsman, J., and Raffa, K. F. 2009. Symbioses: A key driver of insect physiological processes, ecological interactions, evolutionary diversification, and impacts on humans. Environ. Entomol. 38:67-77.

Kirisits, T., and Offenthaler, I. 2002. Xylem sap flow of Norway spruce after inoculation with the blue-stain fungus Ceratocystis polonica. Plant Pathol. 51:359-364.

Kostovcik, M., Bateman, C. C., Kolarik, M., Stelinski, L. L., Jordal, B. H., and Hulcr, J. 2015. The ambrosia symbiosis is specific in some species and promiscuous in others: Evidence from community pyrosequencing. ISME J. 9:126-138.

Kühnholz, S., Borden, J. H., and Uzunovic, A. 2001. Secondary ambrosia beetles in apparently healthy trees: Adaptations, potential causes and suggested research. Inter. Pest Manag. Rev. 6:209-219.

Kuhns, E. H., Tribuiani, Y., Martini, X., Meyer, W. L., Peña, J., Hulcr, J., and Stelinski, L. L. 2014. Volatiles from the symbiotic fungus, Raffaelea lauricola, are synergistic with Manuka lures for increased capture of Redbay ambrosia beetle, Xyleborus glabratus. Agric. For. Entomol. 16:87-94.

Lahav, E., and Lavi, U. 2013. Genetics and breeding. Pages 51-85 in: The Avocado: Botany, Production and Uses, 2nd Edn. B. Schaffer, B. N. Wolstenholme, A. W. Whiley, eds. CAB Int. Publishing, Wallingford, UK.

Li, L., Li, J., Rohwer, J. G., van der Werff, H., Wang, Z.-H., and Li, H.-W. 2011. Molecular phylogenetic analysis of the Persea group (Lauraceae) and its biogeographic implications on the evolution of tropical and subtropical amphi-Pacific disjunctions. Amer. J. Bot. 98:1520-1536.

Mann, R. S., Ali, J. G., Hermann, S. L., Tiwari, S., Pelz-Stelinski, K. S., and Stelinski, L. L. 2012. Induced release of a plant pathogen defense volatile 'deceptively' attracts insect vectors to plants infected with a bacterial pathogen. PloS Pathog. 8(3):e1002610.

Marini, L., Haack, R. A., Rabaglia, R. J., Toffolo, E. P., Battisti, A., and Faccoli, M. 2011. Exploring associations between international trade and environmental factors with establishment patterns of exotic Scolytinae. Biol. Invasions 13:2275-2288.

Martini, X., Hughes, M. A., Smith J. A., and Stelinski, L. L. 2016. Attraction of redbay ambrosia beetle, Xyleborus glabratus, to leaf volatiles of its hosts in North America. J. Chem. Ecol. 41:613-621.

Martini, X., Willett, D., Kuhns, E. H., and Stelinski, L. L. 2016. Disruption of vector host preference with plant volatiles may reduce spread of insect-transmitted plant pathogens. J. Chem. Ecol. 42:357-367.

Mayfield, A. E., III, and Brownie, C. 2013. The redbay ambrosia beetle (Coleoptera: Curculionidae: Scolytinae) uses stem silhouette diameter as a visual host-finding cue. Environ. Entomol. 42:743-750.

Mayfield, A. E., III, and Hanula, J. L. 2012. Effect of tree species and end seal on attractiveness and utility of cut bolts to the redbay ambrosia beetle and granulate ambrosia beetle (Coleoptera: Curculionidae: Scolytinae). J. Econ. Entomol. 105:461470.

Mayfield, A. E., Peña, J. E., Crane, J. H., Smith, J. A., Branch, C. L., Ottoson, E. D., and Hughes, M. 2008. Ability of the redbay ambrosia beetle (Coleoptera: Curculionidae: Scolytinae) to bore into young avocado (Lauraceae) plants and transmit the laurel wilt pathogen (Raffaelea sp.). Fla. Entomol. 91:485-487.

Mickelbart, M. V., Bender, G. S., Witney, G. W., Adams, C., and Arpaia, M. L. 2007. Effects of clonal rootstocks on 'Hass' avocado yield components, alternate bearing, and nutrition. J. Hort. Sci. Biotech. 82:460-466.

Miller, D. R., and Rabaglia, R. J. 2009. Ethanol and (-)- $\alpha$-pinene: Attractant kairomones for bark and ambrosia beetles in the southeastern U.S. J. Chem. Ecol. 35:435-448.

Ngoan, N. D., Wilkinson, R. C., Short, D. E., Moses, C. S., and Mangold, J. R. 1976. Biology of an introduced ambrosia beetle, Xylosandrus compactus, in Florida. Ann. Entomol. Soc. Amer. 69:872-876.

Niogret, J., Epsky, N. D., Schnell, R. J., Boza, E. J., Kendra, P. E., and Heath, R. R. 2013. Terpenoid variations within and among half-sibling avocado trees, Persea americana Mill. (Lauraceae). PLoS One 8:e73601.

Park, J.-H., Juzwik, J., and Cavender-Bares, J. 2013. Multiple Ceratocystis smalleyi infections associated with reduced stem water transport in bitternut hickory. Phytopathology 103:565-574.

Peña, J. E., Carrillo, D., Duncan, R. E., Capinera, J. L., Brar, G., McLean, S., Arpaia, M. L, Focht, E., Smith, J. A., Hughes, M., and Kendra, P. 2012. Susceptibility of Persea spp. and other Lauraceae to attack by redbay ambrosia beetle, Xyleborus glabratus (Coleoptera: Curculionidae: Scolytinae). Fla. Entomol. 95:793-797.

Peña, J. E., Crane, J. H., Capinera, J., Duncan, R., Kendra, P., Ploetz. R., McLean, S., Brar, G., Thomas, M., and Cave, R. 2011. Chemical control of the red bay ambrosia 
beetle, Xyleborus glabratus, and other Scolytinae (Coleoptera: Curculionidae). Fla. Entomol. 94:882-896.

Ploetz, R. C., Harrington, T., Hulcr, J., Fraedrich, S., Smith, J. A., Inch, S., Kendra, P., Mayfield, A. E., Hanula, J., Rabaglia, R., Palmateer, A., Peña, J., Eskalen, A., Crane, J., Faber, B., Bostock, R., Harmon, C., Schnell, R., and Wingfield, W. 2011a. Recovery plan for laurel wilt of avocado (caused by Raffaelea lauricola). HSPD-9, USDA-ARS National Plant Disease Recovery System (NPDRS), Washington, DC. http://www.ars.usda.gov/Research/docs.htm?docid=14271

Ploetz, R. C., Hulcr, J., Wingfield, M., and de Beer, Z. W. 2013. Ambrosia and bark beetle-associated tree diseases: Black Swan events in tree pathology? Plant Dis. 95:856-872.

Ploetz, R. C., Inch, S. A., Pérez-Martínez, J. M., and White, T. L. Jr. 2012a. Systemic infection of avocado, Persea americana, by Raffaelea lauricola, does not progress into fruit pulp or seed. J. Phytopathol. 160:491-495.

Ploetz, R. C., and Konkol, J. 2013. First report of gulf licaria, Licaria trianda, as a suscept of laurel wilt. Plant Dis. 97:1248.

Ploetz, R. C., Konkol, J. L., Narvaez, T., Duncan, R. E., Saucedo, R. J., Campbell, A., Mantilla, J., Kendra, P. E., and Carrillo, D. 2017a. Presence and prevalence of Raffaelea lauricola, cause of laurel wilt, in different species of ambrosia beetle in Florida USA. J. Econ. Entomol. doi:10.1093/jee/tow292.

Ploetz, R. C., Konkol, J. L., Pérez-Martínez, J. M., and Fernandez, R. 2017b. Management of laurel wilt of avocado, caused by Raffaelea lauricola. Eur. J. Plant Pathol. DOI 10.1007/s10658-017-1173-1.

Ploetz, R. C., Peña, J. E., Smith, J. A., Dreaden, T. J., Crane, J. H., Schubert, T., and Dixon, W. 2011b. Laurel wilt is confirmed in Miami-Dade County, center of Florida's commercial avocado production. Plant Dis. 95:1599.

Ploetz, R. C., Pérez-Martínez, J. M., Evans, E. A., and Inch, S. A. 2011c. Toward fungicidal management of laurel wilt of avocado. Plant Dis. 95:977-982.

Ploetz, R. C., Pérez-Martínez, J. M., Smith, J. A., Hughes, M., Dreaden, T. J., Inch, S. A. and Fu, Y. 2012b. Responses of avocado to laurel wilt, caused by Raffaelea lauricola. Plant Pathol. 61:801-808.

Ploetz, R. C., Schaffer, B., Vargas, A. I., Konkol, J. L., Salvatierra, J., and Wideman, R. 2015. Impact of laurel wilt, caused by Raffaelea lauricola, on leaf gas exchange and xylem sap flow in avocado, Persea americana. Phytopathology 105:433-440.

Rabaglia, R. J., Dole, S. A., and Cognato, A. I. 2006. Review of American Xyleborina (Coleoptera: Curculionidae: Scolytinae) occurring north of Mexico, with an illustrated key. Ann. Entomol. Soc. Am. 99:1034-1056.

Ranger, C. M., Reding, M. E., Persad, A. B., and Herms, D. A. 2010. Ability of stressrelated volatiles to attract and induce attacks by Xylosandrus germanus and other ambrosia beetles. Agric. For. Entomol. 12:177-185.

Reding, M. E., Ranger, C. M., Oliver, J. B., and Schultz, P. B. 2013. Monitoring attack and flight activity of Xylosandrus spp. (Coleoptera: Curculionidae: Scolytinae): The influence of temperature on activity. Hort. Entomol. 106:1780-1787.

Sankaran, S., Ehsani, R., Inch, S. A., and Ploetz, R. C. 2012. Evaluation of visible-near infrared reflectance spectra of avocado leaves as a non-destructive sensing tool for detection of vascular infection by the laurel wilt pathogen, Raffaelea lauricola. Plant Dis. 96:1683-1689.

Schoeneweiss, D. F. 1975. Predisposition, stress, and plant disease. Annu. Rev. Phytopathol. 13:193-211.

Simmons, D. R., de Beer, Z. W., Huang, Y.-T., Bateman, C. C., Campbell, A., Dreaden, T. J., Li, Y., Ploetz, R. C., Li, H.-F., Chen, C.-Y., Wingfield, M. J., and Hulcr, J. 2016. New Raffaelea species (Ophiostomataceae) from the United States and Taiwan associated with ambrosia beetles and plant hosts. IMA Fungus 7:265-273.

Sinclair, W. A., and Lyon, J. 2005. Diseases of Trees and Shrubs, 2nd Edn. Cornell Univ. Press., Ithaca, NY.

Six, D. L. 2003. Bark beetle-fungus symbioses. Pages 97-114 in: Insect Symbiosis. K. Bourtzis, and T. Miller, eds. CRC Press, Boca Raton, FL.

Smith, J. A., Dreaden, T. J., Mayfield, A. E., III, Boone, A., Fraedrich, S. W., and Bates, C. 2009a. First report of laurel wilt disease caused by Raffaelea lauricola on sassafras in Florida and South Carolina. Plant Dis. 93:1079.

Smith, J. A., Mount, L., Mayfield, A. E., Bates, C. A., Lamborn, W. A., and Fraedrich, S. W. 2009b. First report of laurel wilt disease caused by Raffaelea lauricola on camphor in Florida and Georgia. Plant Dis. 93:198.

Spence, D. J., Smith, J. A., Hulcr, J., Ploetz, R., and Stelinski, L. L. 2013. Effect of chipping on emergence of the redbay ambrosia beetle (Coleoptera: Curculionidae: 
Scolytinae) and recovery of the laurel wilt pathogen from infested wood chips. J. Econ. Entomol. 106:2093-2100.

Stipes, R. J. 2000. The management of Dutch elm disease. Pages 157-172 in: The Elms: Breeding, Conservation, and Disease Management. C. E. Dunn, ed. Kluwer Academic Publishers, Boston.

Tattar, T. A. 2007. Injection, infusion, and systemic movement in trees. Proc. 2nd Nat. Oak Wilt Sym.. R. F. Billings and D. N. Appel, eds. Texas A\&M FS, USDA-FS, and LBJ Wildflower Center, Austin, TX.

Tobin, P. C., Diss-Torrance, A., Blackburn, L. M., and Brown, B. D. 2010. What does "local" firewood buy you? Managing the risk of invasive species introduction. J. Econ. Entomol. 103:1569-1576.

Urban, J., and Dvořák, M. 2013. Occlusion of sap flow in elm after artificial inoculation with Ophiostoma novo-ulmi. Acta Hort. 991:301-306.

Venturas, M., Lopez, R., Martın, R. A., Gasco, A., and Gil, L. 2014. Heritability of Ulmus minor resistance to Dutch elm disease and its relationship to vessel size, but not to xylem vulnerability to drought. Plant Pathol. 63:500-509.

Willingham, S. L., Pegg, K. G., Anderson, J. M., Cooke, A. W., Dean, J. R., Giblin, F. R., and Coates, L. M. 2006. Effects of rootstock and nitrogen fertiliser on postharvest anthracnose development in Hass avocado. Australas. Plant Pathol. 35:619-629.

\section{Web Resources}

http://www.barkbeetles.info

http://www.ambrosiasymbiosis.org/researchers/jiri-hulcr

https://www.invasivespeciesinfo.gov/microbes/laurelwilt.shtml

UF/IFAS TREC laurel wilt of avocado:

http://trec.ifas.ufl.edu/RAB-LW-2/index.shtml

FDACS Save the Guac:

http://www.freshfromflorida.com/Divisions-Offices/Plant-Industry/Save-the$\underline{\text { Guac }}$

FDACS laurel wilt disease:

http://www.freshfromflorida.com/Divisions-Offices/Plant-Industry/PestsDiseases/Laurel-Wilt-Disease 